NBER WORKING PAPER SERIES

\title{
DID COVID-19 MARKET DISRUPTIONS DISRUPT FOOD SECURITY? EVIDENCE FROM HOUSEHOLDS IN RURAL LIBERIA AND MALAWI
}

\author{
Shilpa Aggarwal \\ Dahyeon Jeong \\ Naresh Kumar \\ David Sungho Park \\ Jonathan Robinson \\ Alan Spearot \\ Working Paper 27932 \\ http://www.nber.org/papers/w27932 \\ NATIONAL BUREAU OF ECONOMIC RESEARCH \\ 1050 Massachusetts Avenue \\ Cambridge, MA 02138
}

October 2020

We are grateful to Jenny Aker for her collaboration. For organizing the data collection, we thank Arja Dayal, Wilson Dorleleay, Walker Higgins, Andreas Holzinger, Erik Jorgensen, Teresa Martens, Laura McCargo and Camelia Vasilov at IPA Liberia, and Patrick Baxter, Emanuele Clemente, Calvin Mhango, Monica Shandal, Patrick Simbewe, and Asman Suleiman at IPA Malawi. We are extremely grateful to all the enumerators who collected this data in both countries, though there are too many to list individually. We thank Joe Amick, Joe-Hoover Gbadyu, Daniel Handel, Scott Jackson, Paul Oliver, Steve Scott and many others at USAID for helpful comments, and we thank Genevieve Barrons, Michael Cooke, Namita Desai, Shaunak Ganguly, and Stephanie Palla at GiveDirectly for their collaboration. We thank Kris Cox and Pace Phillips at IPA for their work setting up the project. This project was administered by the Development Impact Laboratory at CEGA, and we thank Carson Christiano, Samuel Fishman, Gladys Khoury, Temina Madon and Kevin McCarthy for supporting the project. This protocol was approved by the IRBs of the University of California, Santa Cruz, the University of Liberia, and the Malawi National Committee on Research in the Social Sciences and Humanities (NCRSH). This study was funded by USAID, but the findings, interpretations, and conclusions expressed in this paper are entirely those of the authors. They do not necessarily represent the views of USAID, the World Bank and its affiliated organizations, or those of the Executive Directors of the World Bank, the governments they represent, or the National Bureau of Economic Research.

NBER working papers are circulated for discussion and comment purposes. They have not been peer-reviewed or been subject to the review by the NBER Board of Directors that accompanies official NBER publications.

(C) 2020 by Shilpa Aggarwal, Dahyeon Jeong, Naresh Kumar, David Sungho Park, Jonathan Robinson, and Alan Spearot. All rights reserved. Short sections of text, not to exceed two paragraphs, may be quoted without explicit permission provided that full credit, including (C) notice, is given to the source. 
Did COVID-19 Market Disruptions Disrupt Food Security? Evidence from Households in Rural Liberia and Malawi

Shilpa Aggarwal, Dahyeon Jeong, Naresh Kumar, David Sungho Park, Jonathan Robinson, and Alan Spearot

NBER Working Paper No. 27932

October 2020

JEL No. O12,O13,Q12

\section{ABSTRACT}

We quantify the effect of market disruptions due to COVID-19 on the lives of households in rural areas of Liberia and Malawi, utilizing panel data from phone surveys that were implemented as part of a randomized cash transfer experiment. The surveys began collection several months before the pandemic and have continued throughout it. The household survey included a consistent set of internationally accepted and validated questions on food security (the household dietary diversity score, the household hunger scale, and the food consumption score). In both countries, market activity was severely disrupted and we observe large declines in income among market vendors, but we find no evidence of declines in food security for households in the short run. Even though we observe no adverse effects of the lockdowns on food security among the control group, cash transfers improved dietary quality and quantity over the low levels observed at baseline.

Shilpa Aggarwal

Indian School of Business

Gachibowli, Hyderabad 500032

India

shilpa_aggarwal@isb.edu

Dahyeon Jeong

The World Bank

dahyeonjeong@worldbank.org

Naresh Kumar

University of California, Santa Cruz

Santa Cruz, CA 95064

nkumar5@ucsc.edu

\author{
David Sungho Park \\ University of California, Santa Cruz \\ Santa Cruz, CA 95064 \\ davidspark@ucsc.edu \\ Jonathan Robinson \\ University of California, Santa Cruz \\ Santa Cruz, CA 95064 \\ and NBER \\ jmrtwo@ucsc.edu \\ Alan Spearot
University of California, Santa Cruz
Santa Cruz, CA 95064
acspearot@gmail.com
}




\section{Introduction}

Rural Africa has largely been an afterthought during the COVID-19 pandemic, due in part to relatively lower disease prevalence. ${ }^{1}$ Yet while case counts are relatively modest, economic disruptions have been nearly as intense as those in developed countries. ${ }^{2}$ This study focuses on 2 countries: Liberia, which ordered a full shelter-in-place for 3 months, and Malawi, which lacked a shelterin-place but still closed schools and placed restrictions on transportation and gatherings. Both countries restricted cross-border movement.

The impact of these restrictions on rural households is not obvious ex ante. On the one hand, Malawi and Liberia are among the poorest countries in the world; the average household in this study spends less than $\$ 1$ per day and has almost no financial wealth. Safety nets are weak in both countries, much of the workforce is in the informal sector, and governments have limited financial and logistical capacity to identify beneficiaries and provide income assistance. Indeed, in our study areas, no households reported receiving assistance during the pandemic. Many media accounts take this view, warning of millions being pushed into poverty and even of imminent starvation (FAO, IFPRI and WFP (2020)). On the other hand, rural areas are less likely to be affected by the virus itself, because of low population density, remoteness from population centers, and reliance on farming (which can be practiced at social distance). They may also be similarly insulated from the lockdowns - while economic activity in population centers has clearly declined, this may not have spilled over into more rural areas.

We measure the impacts of the COVID lockdowns on well-being using monthly phone surveys with households as well as with food vendors in local markets. The surveys were implemented as part of an ongoing evaluation of a large unconditional cash transfer (UCT) program, and data collection started well before the global onset of COVID-19, and have continued throughout the pandemic. The household survey was conducted every 2 months (with half of the sample interviewed each month) and includes questions on food security, income, labor supply, expenditures, transfers and other related outcomes. The second survey is with food vendors in markets in the study area, as well as in comparable markets elsewhere in the country, and is conducted monthly. This survey includes questions on food prices; in addition, in the weeks following the imposition of COVIDrelated public health measures, we added retrospective questions on market activity including income, revenues, the number of customers, and supply chains. Finally, in both surveys, we added modules specific to COVID-19, including questions on attitudes and behavior changes.

While there has been an explosion of research on the economic impacts of COVID-associated market disruptions, this study makes two main contributions. First and foremost, our household

\footnotetext{
${ }^{1}$ At this writing, according to Worldometer, there have been about 1.5 million cases and 35,000 deaths in Africa (population 1.2 billion), and about half of these are in the country of South Africa. By contrast, North America has approximately 9 million cases and more than 300,000 deaths (population 580 million) while Europe has approximately 5 million cases and 220,000 deaths (population 740 million).

${ }^{2} \mathrm{~A}$ map-visualization of the stringency of the lockdowns (as of May 2020, the height of restrictions), based on the University of Oxford's Government Response Tracker is available here: https://ourworldindata.org/grapher/covidstringency-index?year=2020-05-01.
} 
survey includes standardized questions on food intake, specifically the household dietary diversity score (HDDS), the food consumption score (FCS), and the household hunger scale (HHS). These measures are recommended for use by organizations such as the FAO and USAID, and have been validated in several settings to meaningfully correlate with food security. ${ }^{3}$ Second, we use the cash transfer experiment to evaluate the effect of cash during the lockdowns.

We find that knowledge about the virus was high, that people are concerned about contracting the virus and have changed their behavior consistent with health guidance, and that market disruptions were enforced. We find major declines in market activity in both countries, which is not surprising in Liberia where there was a lockdown, but is important to document in Malawi where there was no official restriction. Food vendors suffered large income losses - monthly profit declined by about $42 \%$ in Malawi and $52 \%$ in Liberia. Effects on prices show no consistent pattern. In Liberia we observe price increases of about $4-9 \%$ for all food items and of $12-20 \%$ for staples such as rice and cassava; in Malawi, we actually observe large declines in prices of food, likely due to the harvest coinciding with the lockdown, and even relative to historical trends.

Yet despite these disruptions, our main result is that we observe no evidence of worsened food security in either country (for either the treatment or control groups in the experiment). This is not because government or NGO support programs mitigated negative effects (no households reported receiving any such support during this period). This finding is not to diminish the fact that in both countries, the level of food security is low - in Liberia, $40 \%$ of households reported at baseline that a household member went to bed hungry in the past month, while in Malawi this percentage was $48 \%$. However, we find that this low level of food security did not further worsen during the market disruptions. We also find that cash transfers modestly improved food security, which is noteworthy because transfers were sent well prior to the crisis. This result is similar to Banerjee et al. (2020), who study the effects of universal basic income (UBI) in Kenya and like us, find modest effects on food security. Our context differs from a UBI, in that the transfers we study pre-date the pandemic onset.

Why are effects so modest? Most respondents in our sample are subsistence farmers, and farming was exempt from restrictions. Respondents do also engage in other income-generating activities like casual labor, or small business, but income from these sources is very limited (less than $\$ 10$ per month), and we observe modest declines. Finally, while markets have been restricted, they were nevertheless open, and the price of food has increased only modestly in Liberia and has actually declined in Malawi.

In this study context, it appears that the remoteness of rural areas, and its reliance on subsistence farming, may have actually helped mitigate negative effects - while economic activity clearly declined in population centers, as well as for market vendors, effects appear much more muted for study households, most of whom are farmers. ${ }^{4}$ While our results are for only 2 countries, they

\footnotetext{
${ }^{3}$ For more information, see the Tufts University's INDDEX project: https://inddex.nutrition.tufts.edu/data4diets/indicators.

${ }^{4}$ Our results share some similarities with Ceballos, Kannan and Kramer (2020), who find that impacts of lockdowns were linked with market integration levels - farmer incomes declined in remote areas where market integration was poorer, but consumption improved because more stocks were available locally. However, we do not observe a decline
} 
suggest that temporary lockdowns can be implemented in rural areas like these, without worsening food insecurity (at least for most households). It is possible that other people in these study areas, such as service workers, suffered during the lockdown; however, these jobs are rare in our study samples. It is also clear that some business owners like vendors lost income during the crisis; although these individuals are better off to start with in our data, it is possible that food security declined for them. Nevertheless, our results suggest that the typical farming household was able to cope, which we believe is an important result given that these 2 countries are among the poorest in the world, and our study samples include people living well below the global poverty line. That being said, we reiterate that these findings could be specific to these areas and could differ in other contexts ${ }^{5}$, and could also differ in future pandemics if lockdowns last longer, since this study focuses only on the short term.

The rest of this paper is organized as follows. Section 2 describes the study context, Section 3 presents results, and Section 4 concludes.

\section{Experimental Design, Background, and Study Context}

This project is based on field work that has been ongoing in Liberia and Malawi since 2018. The design is nearly identical in both countries, with minor context-specific differences. In each country, we are evaluating the effect of UCTs which are being given out by the NGO GiveDirectly (henceforth, GD). The cash transfers average $\$ 500$, roughly equivalent to annual household expenditures. The treatment is randomized at the village level: in treatment villages, all households receive cash, while control villages receive nothing. ${ }^{6}$ Villages were randomly selected to receive $\$ 250, \$ 500$, or $\$ 750$ per household, paid in monthly $\$ 250$ installments, translating into 1,2 , or 3 payments.Additionally, in Liberia, respondents were randomized into being paid in this fashion, or quarterly; in Malawi, households were randomly selected to have the male or female head receive the transfer. Transfers are made via mobile money; since pre-existing mobile money usage is low, beneficiaries are given the option to buy cell phones. ${ }^{7}$

The study areas were chosen by GD and USAID based on poverty levels, cell phone coverage, and proximity to roads. In Liberia, the project takes place in 6 districts $^{8}$ in Bong and Nimba counties. In Malawi, the project takes place in Chiradzulu and Machinga districts in the Southern Region. In Liberia, the project was phased in over 2 years: a first wave (90 villages) was enrolled in early 2019, while a second wave (210 villages) began enrolling in early 2020. However, due

in income in our data.

${ }^{5}$ Indeed, several studies of COVID in Africa find large declines in food security in Uganda (Mahmud and Riley (2020)) and Nigeria (Amare et al. (2020))

${ }^{6}$ The decision to apply universal targeting, i.e. give transfers to everybody, was made with GD to minimize within-village conflict. However, since there is limited funding, this meant working in a few modestly-sized villages. The average number of households in sampled villages was 27 in Liberia and 55 in Malawi. The villages are therefore not meant to be representative of larger villages.

${ }^{7}$ We also cross-cut a "market access" intervention with the cash transfers. We control for this treatment, but it is not a focus.

${ }^{8}$ Year 1 of the study takes place in Salala and Yeallequelleh districts in Bong and Year 2 in the districts of Twan River, Meinpea Mahn, Leewehpea Mahn, and Buu Yao, in Nimba, as well as a part of Yeallequelleh district in Bong. 
to COVID-related disruptions, many villages were not enrolled until late August. In Malawi, all villages were enrolled in 2019. A map of study locations, with pins of the study villages and markets, is included as Appendix Figure A2. Appendix Figure A1 has a timeline of project activities.

In total, 600 villages were sampled (300 in each country), and we attempted to enroll 10 households per village in the study. Where possible, treatment intensity was varied by geographic location (the smallest level of governance above the village), and stratified by TA in Malawi and district/clan in Liberia.

\subsection{COVID-19 disruptions in Liberia and Malawi}

Liberia's response to COVID was typical for Africa. Following the first case on March 16, the country immediately banned entry from countries with more than 200 cases, closed schools, and restricted public transportation. On March 21, the government announced a state of national health emergency, placing restrictions on bars, restaurants, markets, and other gathering places. On March 24, Montserrado and Margibi counties including the capital and the airport) were ordered to shelter in place. Overland borders were closed. On April 8, a state of emergency placed the counties of Montserrado, Margibi, Nimba, and Grand Kru under shelter-in-place starting April 10. This was extended to the entire country on April 24. Restrictions were removed on July 22.

Malawi's response was more atypical, due to a legal challenge upheld by the country's High Court. The government announced a "state of disaster" on March 20th, which mandated school closures, restrictions on public gatherings and on travel. On April 1, the border with Mozambique closed. On April 14, the government announced a country-wide lockdown (due to start on April 18th), but this order was challenged and was overturned by the High Court on April 19th. Without a country-wide lockdown, Malawi's response was one of the weakest in Africa, ranking 57/100 (compared to 88/100 for Libera) on the Oxford COVID-19 Government Response Tracker. ${ }^{9}$

As of this writing, Liberia has had about 1,300 cases and 82 deaths (population of about 5 million), while the corresponding numbers in are Malawi 5,600, 176, and 18 million.

\subsection{Sample selection and surveys}

We drew a sample using information provided by GD. To select villages, GD visited each village considered for study inclusion, where GD field staff marked each habitation structure with a GPS pin. We randomly selected study households from this list of GPS pins, and targeted female heads of households for surveys (because intimate partner violence is a key outcome).

The analysis in this paper is based on two sets of monthly phone surveys, one of households and one of food vendors. We describe these below.

\footnotetext{
${ }^{9}$ https://www.bsg.ox.ac.uk/research/research-projects/coronavirus-government-response-tracker
} 


\subsubsection{Households phone surveys}

Our ongoing evaluation was designed to measure the time-varying effects of cash transfers. We randomly selected 2 households per village to receive cell phones (worth $\$ 10-15$ ), and enumerators called them every 2 months for approximately 10-14 months. ${ }^{10}$

Our main outcome is food security, but the phone survey also included questions on income, expenditures, transfers, savings, and related outcomes. We have 3 measures of food security: (1) the household dietary diversity score (HDDS), which groups foods into 12 categories, and records whether at least one food item in each category was consumed in the past 24 hours; ${ }^{11}$ (2) the food consumption score (FCS), which is similar to HDDS but measures frequency of consumption rather than just indicators for 9 food groups (over the past 7 days), and ranges from $0-112 ;{ }^{12}$ and (3) the household hunger scale (or HHS) is based on a series of 6 questions such as "In the past 4 weeks (30 days), was there ever no food to eat of any kind in your house because of lack of resources to get food?" and "In the past 4 weeks (30 days), did you or any household member go to sleep at night hungry because there was not enough food?" This score ranges from $0-6 .{ }^{13}$

\subsubsection{Surveys of food vendors}

As part of our evaluation, we set up data collection to measure prices in areas where cash was distributed, and in comparison markets. In Liberia, comparison markets were selected throughout other parts of the country, using the WFP Liberia Market Review Report. ${ }^{14}$ We enrolled all markets after excluding the five smallest markets (by number of food vendors), as well as a few additional markets not used by our respondents. We started with 32 markets in Bong in April 2019 and added another 48 from Nimba and other counties in February 2020. In Malawi, we obtained the full official list of markets in the two study districts, Machinga and Chiradzulu, and 7 surrounding districts as comparison. ${ }^{15}$ From this, we sampled the biggest market for each traditional authority (TA), resulting in 95 markets. In total, there are 80 markets (40 treatment and 40 comparison) in Liberia, and 95 markets (25 treatment and 70 control) in Malawi.

We attempted to enroll at least 2 vendors of each product per market, though this was chal-

\footnotetext{
${ }^{10}$ Table A1 shows attrition from the household phone surveys, by treatment status. Columns 1-7 show regression for survey completion round-by-round, while Column 8 shows an indicator for appearing in at least 1 round, and Column 9 shows the percentage of rounds completed. Taking Column 9 as the summary measure, we find that $91 \%$ of surveys were completed in Malawi, and this was similar in treatment and control. In Liberia, completion was much lower: 60\% in Wave 1 and 70\% in Wave 2. Unfortunately, completion is significantly lower among treatment households in Wave 1; this is because households changed their phone numbers when they received the cash transfer offer and so mechanically were harder to reach. We addressed this issue in Wave 2, and attrition is lower and also balanced in Wave 2. However, due to this issue, we do not present Wave 1 results in the main regressions (though we do show them in the appendix, Table A6); we also have very limited data from Wave 2, since enrollment in the treatment was disrupted by COVID (whereas the surveys themselves were not, allowing us to examine the impact of COVID.

${ }^{11}$ These survey questions were based on guidance in FAO 2013.

${ }^{12}$ These survey questions were based on guidance in WFP 2008.

${ }^{13}$ These survey questions were based on guidance in Ballard et al. 2011.

${ }^{14}$ https://documents.wfp.org/stellent/groups/public/documents/ena/wfp188456.pdf

${ }^{15}$ These are Balaka, Blantyre, Mangochi, Mulanje, Phalombe, Thyolo, and Zomba.
} 
lenging in smaller markets. We measured only food prices (given the importance of food in local consumption baskets), and selected items based on their frequency in consumption and production as found in existing household surveys (HIES for Liberia and IHS4 for Malawi) as well as our own baseline survey. We collected prices for 14 items in Liberia ${ }^{16}$ and 16 in Malawi. ${ }^{17}$ We enrolled $~ 900$ vendors in Liberia and 1,200 in Malawi, and called them once per month. Prior to COVID, these surveys focused only on prices. We asked each vendor about the products that she sold ("direct prices") as well as the prices of other items on the list ("indirect prices"); we did this because some items were rarely sold in smaller markets and finding their prices was challenging. However, we use direct prices whenever possible.

\subsubsection{COVID-related questions}

Shortly after the lockdowns began, we redesigned our phone surveys to measure the impact of the unfolding crisis. These surveys started in May after all IRB approvals. The new surveys included several modules. First, we asked a series of questions about knowledge, attitudes and behavior changes around COVID. These questions were designed using other available surveys and so are similar to those used in other contexts. Second, we added modules to retrospectively measure outcomes that had not been measured previously. For households, we added questions on spousal labor income as well as business outcomes. For food vendors, we added questions on quantities sold, the number of customers, revenues, profits, and income from other sources. To construct a comparison month, we measured these month-by-month from February 2020.

\subsection{Summary statistics}

Table 1 presents summary statistics. From Panel A, the vast majority of the sample is female (since we targeted female heads), and the average respondent is 40 years old. Most respondents are married and the average household has 4-5 members. Panel B shows data on income, expenditures, and assets. The vast majority of the sample earns income from farming, and only $21-25 \%$ report having a business. The average household spends about US $\$ 38-42$ per month, which works out to less than $\$ 0.30$ per day per capita.

The average household has about $\$ 400$ in assets in Liberia and $\$ 1,500$ in Malawi, but the majority of this is in the form of land and housing - other assets are only $\$ 20$ in Liberia, and less than $\$ 100$ in Malawi. Financial assets are almost non-existent: cash savings is less than $\$ 10$ in each country, and outstanding household debt is similarly sized; in fact, household net financial wealth is negative in Malawi and only $\$ 2$ in Liberia.

Panel C documents food security. While our main results will show indices as described above, we present some intuitive components of those indices here, since they are more understandable.

\footnotetext{
${ }^{16}$ The items are salt, imported rice, local rice, cassava, cassava flour, chicken, fresh fish, dried fish, palm oil, pepper, bitter balls, okra, onions and sugarcane juice.

${ }^{17}$ The items are salt, sugar, sweet potatoes, rice, maize, maize flour, chicken, soybeans, dried fish, mpiru (a local vegetable), beans, groundnuts, tomatoes, eggs, onions, and pigeon peas.
} 
We find that $40-44 \%$ of respondents report skipping a meal in the past month because there was not enough food, and almost a quarter experienced no food for an entire day.

Table 1: Household Demographics

\begin{tabular}{|c|c|c|c|c|}
\hline & \multicolumn{2}{|c|}{ Liberia } & \multicolumn{2}{|c|}{ Malawi } \\
\hline & Mean & SD & Mean & $\mathrm{SD}$ \\
\hline \multicolumn{5}{|l|}{ Panel A: Demographics } \\
\hline$=1$ if female & 0.79 & & 0.95 & \\
\hline Age & 40.32 & 14.53 & 38.79 & 14.62 \\
\hline$=1$ if currently married or has partner & 0.83 & & 0.69 & \\
\hline Years of education & 2.68 & 3.50 & 5.04 & 3.43 \\
\hline Number of household members & 4.53 & 2.19 & 4.73 & 2.08 \\
\hline \multicolumn{5}{|l|}{ Panel B: Income, expenditure, and assets } \\
\hline$=1$ planted any crop in most recent agriculture season & 0.89 & 0.32 & 0.99 & 0.11 \\
\hline$=1$ if sold any harvest & 0.56 & 0.50 & 0.52 & 0.50 \\
\hline$=1$ if owns a business enterprise & 0.21 & 0.41 & 0.25 & 0.43 \\
\hline Household monthly expenditure & 36.43 & 42.12 & 43.82 & 52.25 \\
\hline Household food expenditure & 5.59 & 13.09 & 15.00 & 15.97 \\
\hline$=1$ if respondent has access to mobile phone ${ }^{\mathrm{a}}$ & 0.19 & 0.39 & 0.31 & 0.46 \\
\hline$=1$ if house owned & 0.66 & 0.47 & 0.85 & 0.35 \\
\hline$=1$ if house has thatch roof & 0.26 & 0.44 & 0.51 & 0.50 \\
\hline Total value of land and housing & 255.53 & 498.73 & $1,398.11$ & $2,404.06$ \\
\hline Total net value of durable goods, livestock, and financial asset & 15.10 & 35.01 & 86.35 & 144.16 \\
\hline Total value of physical assets & 13.26 & 29.48 & 89.25 & 143.05 \\
\hline Net value of financial assets & 1.85 & 21.38 & -2.89 & 14.91 \\
\hline Savings & 5.72 & 16.33 & 4.00 & 9.42 \\
\hline Outstanding household debt & 3.88 & 13.39 & 6.89 & 14.97 \\
\hline \multicolumn{5}{|l|}{ Panel C: Food security } \\
\hline \multicolumn{5}{|l|}{ For any household member in the past month: } \\
\hline$=1$ if skipped a meal & 0.44 & & 0.40 & \\
\hline$=1$ if went to sleep hungry & 0.40 & & 0.48 & \\
\hline$=1$ if had no food for an entire day & 0.23 & & 0.27 & \\
\hline Observations & \multicolumn{2}{|c|}{593} & \multicolumn{2}{|c|}{596} \\
\hline
\end{tabular}

Note: Outcomes from the baseline survey. All monetary values are in USD and Winsorized at 99\%. Exchange rates used for calculation are 733 Malawian Kwacha $($ MWK $)=1$ USD and 198 Liberian Dollars $(\mathrm{LRD})=1$ USD $($ May 14, 2020).

a This was measured before we provided a mobile phone.

\section{Quantifying the Effect of COVID-19 Market Disruptions}

\subsection{Regression Specifications}

\subsubsection{Individual level outcomes}

We restrict this analysis to data collected between January and August 2020. In most cases, we drop March 2020 (since restrictions came into force mid-month) and run the following specification 
using February 2020 as a reference group:

$$
y_{i t}=\sum_{t=A p r}^{A u g} D_{t}+\theta y_{i o}+\mu_{s}+\epsilon_{i t}
$$

where $D_{t}$ is a month fixed effect, $\mu_{s}$ is a strata fixed effect, and $y_{i o}$ is a measure of the dependent variable collected during baseline (making the specification ANCOVA). For outcomes that were measured retrospectively, we do not include the baseline control.

\subsubsection{Prices}

In each market, we attempted to collect at least 2 price points for each item. We construct a market-level price as the average price in the market, using direct prices where available, and run regressions very similar to (1):

$$
p_{m j t}=\sum_{t=A p r}^{A u g} D_{t}+\mu_{m}+\gamma_{p}+\epsilon_{i t}
$$

where $\mu_{m}$ and $\gamma_{p}$ are market and product fixed effects.

\subsection{Descriptive evidence on disruptions}

Table 2 documents that government measures disrupted overall economic activity. Panel A shows that in Liberia, all activities were almost universally restricted. The extent of disruptions is much smaller in Malawi, but nevertheless schools, religious centers and public transportation were restricted or closed.

Panel B shows summary statistics of self-reported behavior changes. Almost everyone in both countries reports that they stopped shaking hands, started washing hands more frequently, and followed social distancing norms. A significant fraction of people reported limiting travel and wearing masks. ${ }^{18}$

Panel C presents economic disruptions as reported by food vendors. Again, the disruption is felt more strongly in Liberia, where 98 percent of vendors reporting that they are closed or reduced business hours, relative to 25 percent in Malawi. Vendors report difficulty sourcing supplies, and report that the cost of stocking the same bundle of supplies as they did in February would cost $35 \%$ more in Liberia and 22\% more in Malawi. Table A3 shows statistics on income losses, using retrospective data. We find large reductions in profits in Liberia, declining to almost zero by May 2020, and smaller but still substantial losses in Malawi of about $40 \%$ in April and 20\% in June.

\footnotetext{
${ }^{18}$ Table A2 shows a few other selected indicators. Respondents are universally aware of the virus, and levels of concern about it are quite high (this is true even in Malawi where public health measures were more muted). Respondents overwhelmingly trust information coming from the government, and take the virus as a serious threat. However, from Panel C, no households in Malawi reported any assistance to cope with the crisis (the data for Liberia has not been collected yet).
} 
Table 2: Disruptions

\begin{tabular}{|c|c|c|}
\hline & Liberia & Malawi \\
\hline $\begin{array}{l}\text { Panel A: Economics activities } \\
=1 \text { if following places/activities were closed/restricted: } \\
\text { schools (e.g. public, private, universities, colleges, etc.) } \\
\text { markets } \\
\text { retail shops } \\
\text { restaurants } \\
\text { entertainment centers (e.g. bars, clubs, betting centers, etc.) } \\
\text { religious centers (e.g. churches and mosques) } \\
\text { barber shops, beauty salons } \\
\text { supermarkets } \\
\text { gas stations } \\
\text { public transportation } \\
\text { street selling } \\
\text { mobile money agents }\end{array}$ & $\begin{array}{l}0.98 \\
0.93 \\
0.90 \\
0.95 \\
0.95 \\
0.86 \\
0.92 \\
0.96 \\
0.90 \\
0.90 \\
0.89 \\
0.89\end{array}$ & $\begin{array}{l}0.99 \\
0.15 \\
0.11 \\
0.19 \\
0.28 \\
0.71 \\
0.12 \\
0.17 \\
0.09 \\
0.67 \\
0.20 \\
0.10\end{array}$ \\
\hline $\begin{array}{l}\text { Panel B: Behavior changes } \\
=1 \text { if: } \\
\text { traveled less to shops or markets } \\
\text { started wearing a mask } \\
\text { stopped shaking hands } \\
\text { washed hands more often } \\
\text { cleaned things I touch more often } \\
\text { stopped going to religious services } \\
\text { kept social distance from people }\end{array}$ & $\begin{array}{l}0.93 \\
0.77 \\
0.97 \\
0.94 \\
0.73 \\
0.90 \\
0.96\end{array}$ & $\begin{array}{l}0.57 \\
0.32 \\
0.95 \\
0.95 \\
0.46 \\
0.59 \\
0.85\end{array}$ \\
\hline Observations & 983 & 1,548 \\
\hline $\begin{array}{l}\text { Panel C: Business disruptions on Crop Vendors } \\
=1 \text { if: } \\
\text { closed or reduced business hours } \\
\text { inventory spoiled } \\
\text { consumed inventory for myself } \\
\text { supply source changed } \\
\text { Change in supply price from Feb to Now }(\%)^{\mathrm{a}}\end{array}$ & $\begin{array}{c}0.98 \\
0.23 \\
0.44 \\
0.33 \\
38.14 \\
(40.26)\end{array}$ & $\begin{array}{c}0.25 \\
0.18 \\
0.12 \\
0.09 \\
22.57 \\
(47.19)\end{array}$ \\
\hline Observations & 654 & 1,021 \\
\hline
\end{tabular}

Note: Means reported and standard deviations in parentheses. Data comes from first survey after COVID disruptions (in May-July 2020). Panel A and B sample includes both food vendors and households, while Panel C includes food vendors only.

${ }^{a}$ This is calculated from the reported cost of procuring a fixed bundle of items February versus when the survey was conducted, which ranges from May-July 2020.

\section{3 $\quad$ Effects on food prices}

Table 3 shows effects on food prices (Columns 1-4 are for Liberia and 5-8 are for Malawi). Columns 1 and 5 capture effects on all items and show that prices have increased by $3-9 \%$ during the postCOVID period in Liberia (relative to February), but actually declined by about $20-24 \%$ in Malawi. When restricted to staple crops in column 2, prices increased by 18-20\% in Liberia and declined by even more (29-36\%) in Malawi. Since these price changes are purely temporal, changes due to the lockdowns are indistinguishable from seasonal trends, which are important in Malawi, since the this 
area harvests around March. To account for historical monthly price trends, we use the 2011-2019 data series from the WFP for available crops. ${ }^{19}$ In each country, we focus on the primary staple crop - rice in Liberia, and maize in Malawi. This data is available for an unbalanced sample of 23 markets in Liberia and 115 in Malawi. Seasonal price trends for these crops are shown in Figure A4. Columns 3 and 7 show price trends for these crops only, and shows a $5-10 \%$ increase in Liberia and a large decrease of $66-77 \%$ in Malawi (due to the harvest). When we control for seasonal trends, price trends became negative in Liberia (because rice prices traditionally rise slightly during this period), but estimates decline somewhat in Malawi, though they are still large (53-66\%). Anecdotally, the large decline in Malawi appears due to a bumper harvest. ${ }^{20}$

Table 3: Crop Prices

\begin{tabular}{|c|c|c|c|c|c|c|c|c|}
\hline & \multicolumn{8}{|c|}{ Dep. Variable: Log Prices } \\
\hline & \multicolumn{4}{|c|}{ Liberia } & \multicolumn{4}{|c|}{ Malawi } \\
\hline & $(1)$ & $(2)$ & $(3)$ & $(4)$ & $(5)$ & $(6)$ & $(7)$ & $(8)$ \\
\hline & All & Staples & Rice & Rice & All & Staples & Maize & Maize \\
\hline April & $\begin{array}{c}0.078^{* * *} \\
(0.019)\end{array}$ & $\begin{array}{c}0.180^{* * *} \\
(0.022)\end{array}$ & $\begin{array}{c}0.067^{* * *} \\
(0.011)\end{array}$ & $\begin{array}{c}0.074^{* * *} \\
(0.011)\end{array}$ & $\begin{array}{c}-0.197^{* * *} \\
(0.009)\end{array}$ & $\begin{array}{c}-0.292^{* * *} \\
(0.012)\end{array}$ & $\begin{array}{c}-0.767^{* * *} \\
(0.022)\end{array}$ & $\begin{array}{c}-0.659^{* * *} \\
(0.022)\end{array}$ \\
\hline May & $\begin{array}{c}0.085^{* * *} \\
(0.020)\end{array}$ & $\begin{array}{c}0.196^{* * *} \\
(0.022)\end{array}$ & $\begin{array}{c}0.069^{* * *} \\
(0.011)\end{array}$ & $\begin{array}{c}-0.077^{* * *} \\
(0.011)\end{array}$ & $\begin{array}{c}-0.212^{* * *} \\
(0.013)\end{array}$ & $\begin{array}{c}-0.306^{* * *} \\
(0.014)\end{array}$ & $\begin{array}{c}-0.732^{* * *} \\
(0.021)\end{array}$ & $\begin{array}{c}-0.525^{* * *} \\
(0.021)\end{array}$ \\
\hline June & $\begin{array}{c}0.037^{* *} \\
(0.018)\end{array}$ & $\begin{array}{c}0.172^{* * *} \\
(0.022)\end{array}$ & $\begin{array}{c}0.047^{* * *} \\
(0.012)\end{array}$ & $\begin{array}{c}-0.070^{* * *} \\
(0.012)\end{array}$ & $\begin{array}{c}-0.238^{* * *} \\
(0.010)\end{array}$ & $\begin{array}{c}-0.363^{* * *} \\
(0.015)\end{array}$ & $\begin{array}{c}-0.706^{* * *} \\
(0.015)\end{array}$ & $\begin{array}{c}-0.542^{* * *} \\
(0.015)\end{array}$ \\
\hline July & $\begin{array}{c}0.032^{*} \\
(0.019)\end{array}$ & $\begin{array}{c}0.185^{* * *} \\
(0.024)\end{array}$ & $\begin{array}{c}0.104^{* * *} \\
(0.014)\end{array}$ & $\begin{array}{c}-0.152^{* * *} \\
(0.014)\end{array}$ & $\begin{array}{c}-0.232^{* * *} \\
(0.010)\end{array}$ & $\begin{array}{c}-0.362^{* * *} \\
(0.013)\end{array}$ & $\begin{array}{c}-0.660^{* * *} \\
(0.014)\end{array}$ & $\begin{array}{c}-0.658^{* * *} \\
(0.014)\end{array}$ \\
\hline August & $\begin{array}{c}0.045^{* *} \\
(0.018)\end{array}$ & $\begin{array}{c}0.170^{* * *} \\
(0.022)\end{array}$ & $\begin{array}{c}0.090^{* * *} \\
(0.013)\end{array}$ & $\begin{array}{c}-0.122^{* * *} \\
(0.013)\end{array}$ & $\begin{array}{c}-0.199^{* * *} \\
(0.009)\end{array}$ & $\begin{array}{c}-0.302^{* * *} \\
(0.012)\end{array}$ & $\begin{array}{c}-0.647^{* * *} \\
(0.013)\end{array}$ & $\begin{array}{c}-0.546^{* * *} \\
(0.013)\end{array}$ \\
\hline Controls for Price Trend & $\mathrm{N}$ & $\mathrm{N}$ & $\mathrm{N}$ & $\mathrm{Y}$ & $\mathrm{N}$ & $\mathrm{N}$ & $\mathrm{N}$ & $\mathrm{Y}$ \\
\hline Markets & 80 & 80 & 80 & 80 & 95 & 95 & 94 & 94 \\
\hline Products & 14 & 4 & 1 & 1 & 16 & 5 & 1 & 1 \\
\hline Observations & 6331 & 1761 & 473 & 473 & 7017 & 2464 & 549 & 549 \\
\hline Feb Mean (USD) & 1.579 & 0.554 & 0.682 & 0.682 & 0.849 & 0.703 & 0.493 & 0.493 \\
\hline
\end{tabular}

Note: All monetary values are in USD and winsorized at p1 and p99. February is the omitted group. Standard errors are clustered at the market level. Staple crops in Liberia are local rice, imported rice, cassava, and cassva flour. Staple crops in Malawi are sweet potatoes, maize, maize flour, beans, and pigeon peas. Columns 3 and 4 look at imported rice and Columns 7 and 8 look at maize. Additionally, in Columns 4 and 8, the long run monthly averarge prices from the WFP 2011-2019 price database are subtracted from the monthly imported rice and maize prices, respectively. All specifications include product fixed effects and market fixed effects.

\subsection{Effects on households}

We present our main result - the impact of the lockdowns on food security, in Figure 1. Our outcome variable is a composite food security index (henceforth, FSI) of three different indices of

\footnotetext{
${ }^{19}$ WFP's price data for Malawi start from 1998 and for Liberia from 2006 but with fewer number of markets and items. More information about how WFP collects these prices is here: https://documents.wfp.org/stellent/groups/public/documents/manual_guide_proced/wfp291385.pdf

${ }^{20}$ Table A4 shows effects on soap and cleaning products, and shows increases in prices across the board. Effects seem modest for disinfectant and soap, but the price of water buckets almost doubled.
} 
food security - FCS, HDDS, and HHS. ${ }^{21}$ We present three independent data series - Malawi, and the two Liberia waves. To ensure that results are unconfounded by the effects of cash, we present the control groups only.

Mirroring our discussion about seasonality in Section 4.2, we observe that the temporal distribution of the FSI jumps around considerably. ${ }^{22}$ For all 3 samples, we find no decline in food security during the lockdown. Table A5 shows these results in regression form, showing that these changes are statistically significant in many cases.

Figure 1: Changes in food security, pre- and post-COVID

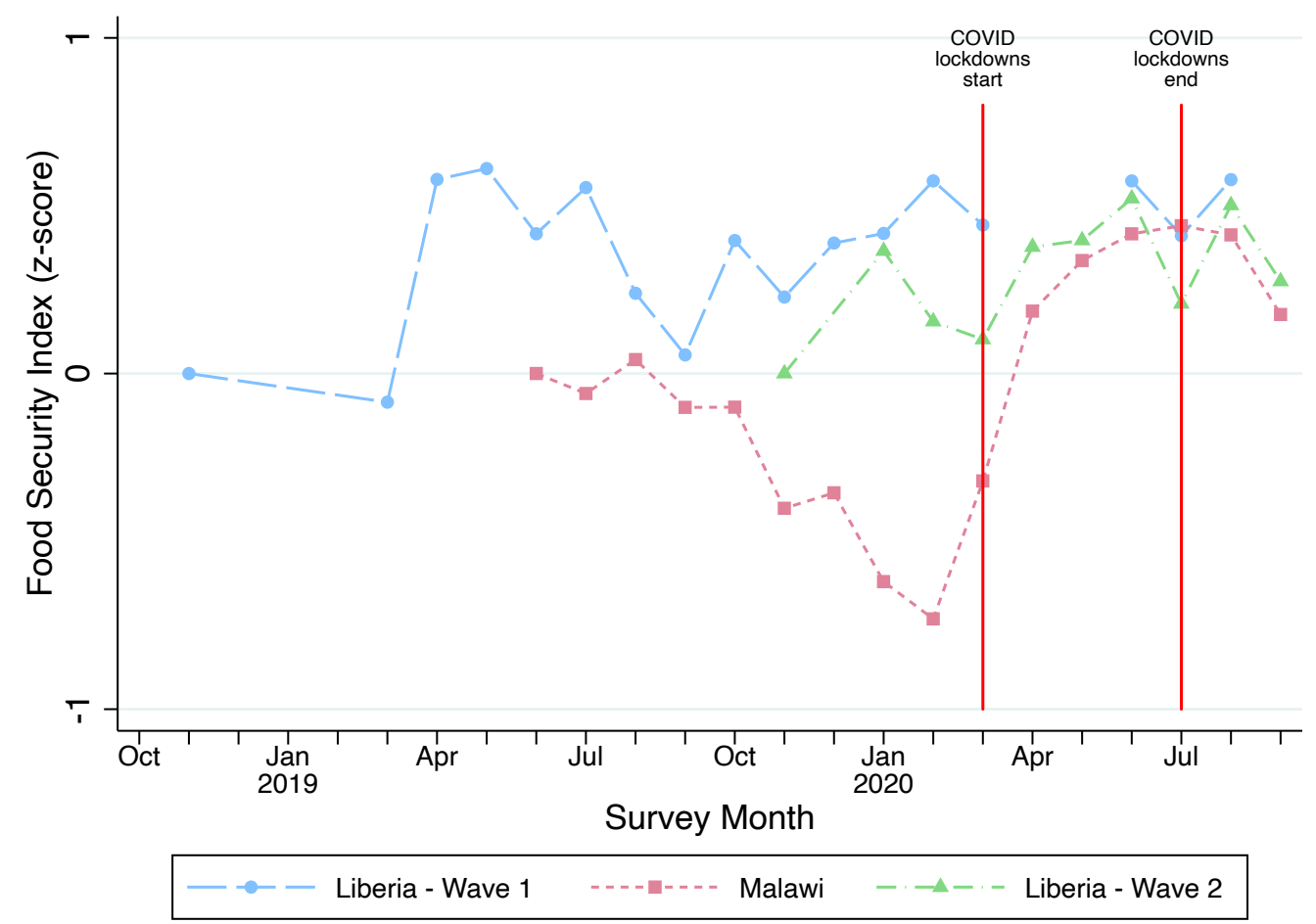

Note: The dependent variable is a standardized index of the household dietary diversity score (HDDS), the food consumption score (FCS), and the household hunger scale (HHS). The recall period is 24 hours for the HDDS, one week for the FCS, and four weeks for the HHS. The figure shows the average for the control group only. There are 75 respondents in Liberia Wave 1, 174 in Liberia Wave 2, and 296 in Malawi. The empty data points for Liberia's Wave 1 sample indicate when there was a pause of data collection for that sample.

For Malawi, we observe an increase in the FSI after March 2020. This result is likely due to the fortuituous fact that the harvest in Southern Malawi begins around March. To shed some light on whether 2020 trends were similar to other years, we use data from the 2010 and 2016 rounds of the Malawi IHS for the Southern Province (where Chiradzulu and Machinga are located) to

\footnotetext{
${ }^{21}$ Since lower values of HHS is better, the FSI includes the inverted value of the HHS. Figure A5 shows each component separately - results are similar for all of them.

${ }^{22}$ The peaks and troughs for Liberia Wave 1 (the only series with sufficiently long coverage) coincide around the same months in both the years.
} 
examine how responses to similar food security questions change over time (this is identified off of non-random survey rollout, and should be taken with caution)- results are presented in Appendix Figures A6 and A7. For both years, we observe an improvement in the FCS and a decrease in household hunger around March, though these effects are typically more modest. ${ }^{23}$ As noted above, price declines were also larger than usual during this time period, which may be explained by the bumper maize harvest in Malawi in $2020 .^{24}$

\subsection{Effects of cash transfers}

Table 4 shows the impacts of cash transfers on FSI (and its components) during the pandemic period (March-July 2020). We limit the main analysis to Malawi only because (as discussed in footnote 10) the Wave 1 phone survey sample was not balanced (due to a technical problem around sim cards) and the rollout of the Wave 2 cash transfers was disrupted by COVID. In Malawi, we find higher food security among cash transfer beneficiaries on all food security indicators, and observe higher spending on food. However, since food security did not decline for the control group in the first place (Figure 1), these effects represent an increase in consumption, rather than a smaller decrease (i.e., mitigation).

Table 4: Cash Effects on Food Security

\begin{tabular}{|c|c|c|c|c|c|}
\hline & (1) & $(2)$ & $(3)$ & $(4)$ & (5) \\
\hline & $\mathrm{HDDS}^{\mathrm{a}}$ & $\mathrm{FCS}^{\mathrm{b}}$ & $\mathrm{HHS}^{\mathrm{c}}$ & $\begin{array}{c}\text { Food } \\
\text { Security } \\
\text { Index }^{\mathrm{d}}\end{array}$ & $\begin{array}{c}\text { Food } \\
\text { Expenditure }\end{array}$ \\
\hline GD & $\begin{array}{c}0.19^{* *} \\
(0.10)\end{array}$ & $\begin{array}{l}1.92^{* *} \\
(0.93)\end{array}$ & $\begin{array}{l}-0.10^{*} \\
(0.06)\end{array}$ & $\begin{array}{c}0.16^{* *} \\
(0.07)\end{array}$ & $\begin{array}{l}1.49^{*} \\
(0.85)\end{array}$ \\
\hline Control Mean & 5.51 & 48.94 & 0.73 & 0.45 & 14.34 \\
\hline Control SD & 1.54 & 13.60 & 1.00 & 1.04 & 12.73 \\
\hline Observations & 1,656 & 1,656 & 1,656 & 1,656 & 1,656 \\
\hline
\end{tabular}

Note: Regressions include survey month and strata fixed effects, and baseline measures of the dependent variable. Standard errors are clustered at village level. Sample includes 595 households in Malawi during the period of March-August 2020.

${ }^{\text {a }}$ Household dietary diversity score (HDDS) ranges from 0 (less diverse) to 12 (more diverse).

${ }^{\mathrm{b}}$ Food consumption score (FCS) ranges from 0 (worse) to 112 (better).

${ }^{\mathrm{c}}$ Household hunger scale (HHS) ranges from 0 (less severe) to 6 (more severe).

d Standardized z-score of HDDS, FCS, and HHS (negatively weighted), using means and standard deviations from control group in March 2020.

The Liberia results show a similar pattern (subject to the above caveats). Table A6 shows Lee bounds for Wave 1. The uncorrected estimate is positive and significant, though the bounds include zero. For Wave 2, the rollout of cash was only partially completed in several districts due to

\footnotetext{
${ }^{23}$ We are unable to replicate this analysis for Liberia using the HIES as the sample size for the relevant counties Bong and Nimba - is too small to support any conclusive findings.

${ }^{24}$ https://reliefweb.int/report/malawi/giews-country-brief-malawi-03-august-2020
} 
COVID; we can therefore create an ITT estimate by comparing the treatment and control groups in these districts. However, this is underpowered since a large portion (63\%) of the assigned treatment villages were untreated; we therefore also compute TOT estimates. As can be seen in Appendix Table A7, the estimates are similar to the Malawi results, though (unsurprisingly) not significant.

\section{Conclusion}

We document the effect of COVID-19 market disruptions in Liberia and Malawi using a panel of phone surveys of households and food vendors. We find high levels of awareness and behavior change and large declines in market activity. However, we find no evidence of increased food insecurity.

While we do not want to over-generalize from this research (since these are just 2 data points), at least for these contexts it appears that the worst fears about lockdowns have not occurred. Our results suggest that lockdowns can be implemented in rural areas if necessary, without causing huge increases in food insecurity (at least for some amount of time), even in very poor settings. The disease itself has not yet spread widely in rural Africa, and activities like subsistence farming have apparently continued with modest disruption. In our sample, people earn very little money from sources other than farming, and this income did not decline much. ${ }^{25}$ Similarly, in other contexts, people have worried about the loss of services such as school meals - yet in this setting, kids were not getting meals in the first place anyway, so there was little to lose. ${ }^{26}$ In this context, market disruptions - which limit but do not eliminate economic activity, and which are not accompanied by a direct loss of assets - might be much easier to cope with than natural disasters, even for people at the bottom of the pyramid.

\footnotetext{
${ }^{25}$ Table A8 shows that income from other sources is only a few dollars per month, and while this did decline in both countries, this still involved small sums.

${ }^{26}$ Table A9 shows that few children received meals and most of these were just replaced by parents..
} 


\section{References}

Amare, Mulubrhan, Kibrom A. Abay, Luca Tiberti, and Jordan Chamberlin. 2020. "Impacts of COVID-19 on food security panel data evidence from Nigeria." International Food Policy Research Institute.

Ballard, Terri, Jennifer Coates, Anne Swindale, and Megan Deitchler. 2011. "Household Hunger Scale: Indicator Definition and Measurement Guide." Food and Nutrition Technical Assistance II Project, FHI 360.

Banerjee, Abhijit, Michael Faye, Alan Krueger, Paul Niehaus, and Tavneet Suri. 2020. "Effects of a Universal Basic Income during the pandemic." Unpublished.

Ceballos, Francisco, Samyuktha Kannan, and Berber Kramer. 2020. "Impacts of a national lockdown on smallholder farmers' income and food security: Empirical evidence from two states in India." World Development, 136: 105069.

FAO. 2013. "Guidelines for measuring household and individual dietary diversity."

FAO, IFPRI, and WFP. 2020. "2020 Global Report on Food Crises."

Mahmud, Mahreen, and Emma Riley. 2020. "Household Response to an Extreme Shock: Evidence on the Immediate Impact of the Covid-19 Lockdown on Economic Outcomes and Wellbeing in Rural Uganda." Unpublished.

WFP. 2008. "Food consumption analysis: Calculation and use of the food consumption score in food security analysis." 


\section{Appendix}

Figure A1: Timeline of Project Activities

\begin{tabular}{|c|c|c|c|c|c|c|c|c|c|c|c|c|c|c|c|c|c|c|c|c|c|c|c|c|c|c|}
\hline & \multicolumn{2}{|c|}{2018} & \multicolumn{12}{|c|}{2019} & \multicolumn{12}{|c|}{2020} \\
\hline & 11 & 12 & 1 & 2 & 3 & 4 & 5 & 6 & 7 & 8 & 9 & 10 & 11 & 12 & 1 & 2 & 3 & 4 & 5 & 6 & 7 & 8 & 9 & 10 & 11 & 12 \\
\hline \multicolumn{27}{|l|}{ Malawi } \\
\hline \multicolumn{27}{|l|}{ Baseline } \\
\hline \multicolumn{27}{|l|}{ Crop Vendor Phone Surveys } \\
\hline \multicolumn{27}{|l|}{ Cash Transfers } \\
\hline \multirow{2}{*}{\multicolumn{27}{|c|}{ Liberia }} \\
\hline \multicolumn{15}{|l|}{ Wave 1 Baseline } & & & & & & & & & & & & \\
\hline \multicolumn{27}{|l|}{ Wave 1 Household Phone Surveys } \\
\hline \multicolumn{27}{|l|}{ Wave 1 Cash Transfers } \\
\hline \multicolumn{27}{|l|}{ Crop Vendor Phone Surveys } \\
\hline \multicolumn{27}{|l|}{ Wave 2 Baseline } \\
\hline \multicolumn{27}{|l|}{ Wave 2 Household Phone Surveys } \\
\hline Wave 2 Cash Transfers & & & & & & & & & & & & & & & & & & & & & & & & & & \\
\hline
\end{tabular}

Note: Data collection for phone surveys and endline continue in 2021, but they were omitted from this figure. 
Figure A2: Map of Study Villages and Markets in Liberia and Malawi

(a) Liberia

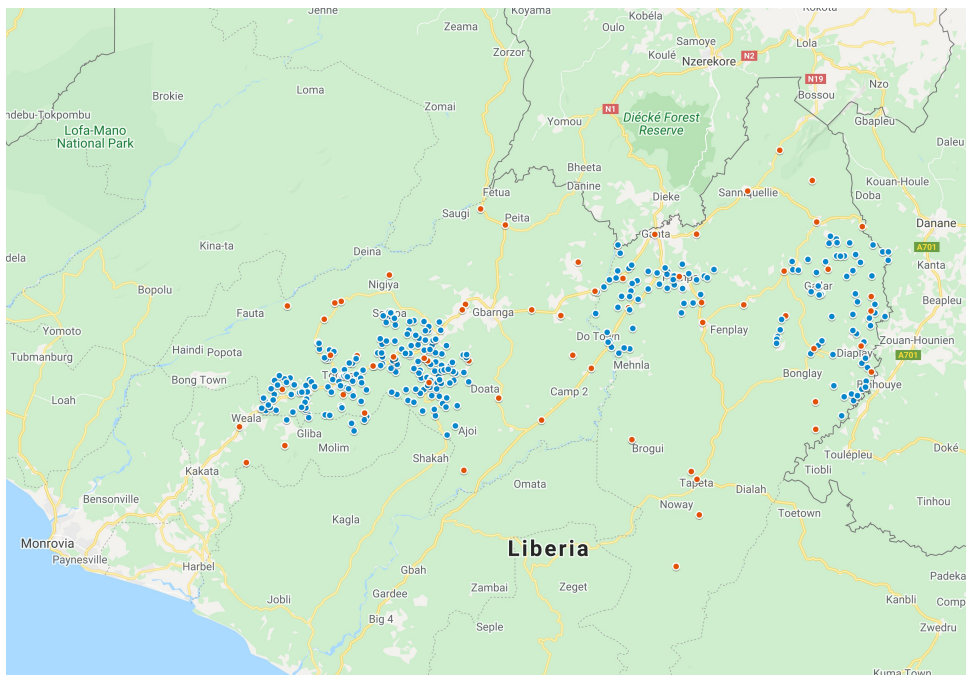

(b) Malawi

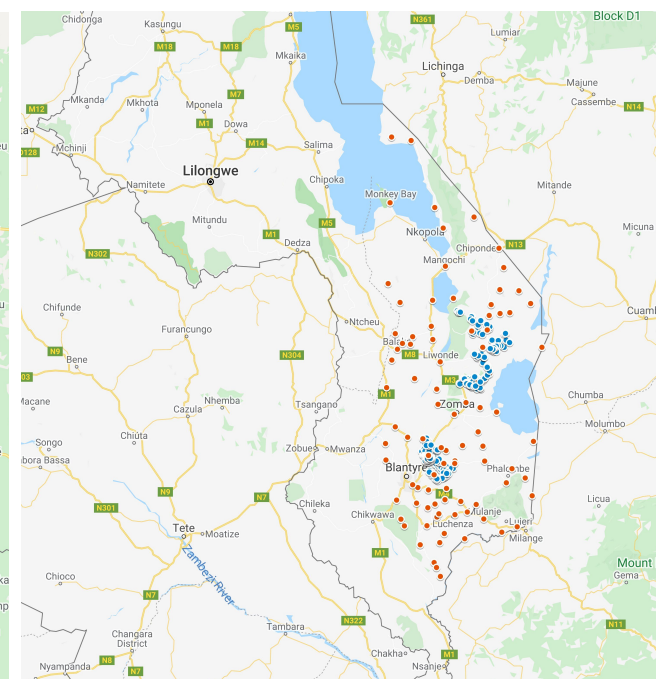

Note: Blue dots refer to villages, and orange dots markets. For Liberia, there are 300 villages and 80 markets. For Malawi, there are 300 villages and 95 markets.

Figure A3: Timeline of Government Responses

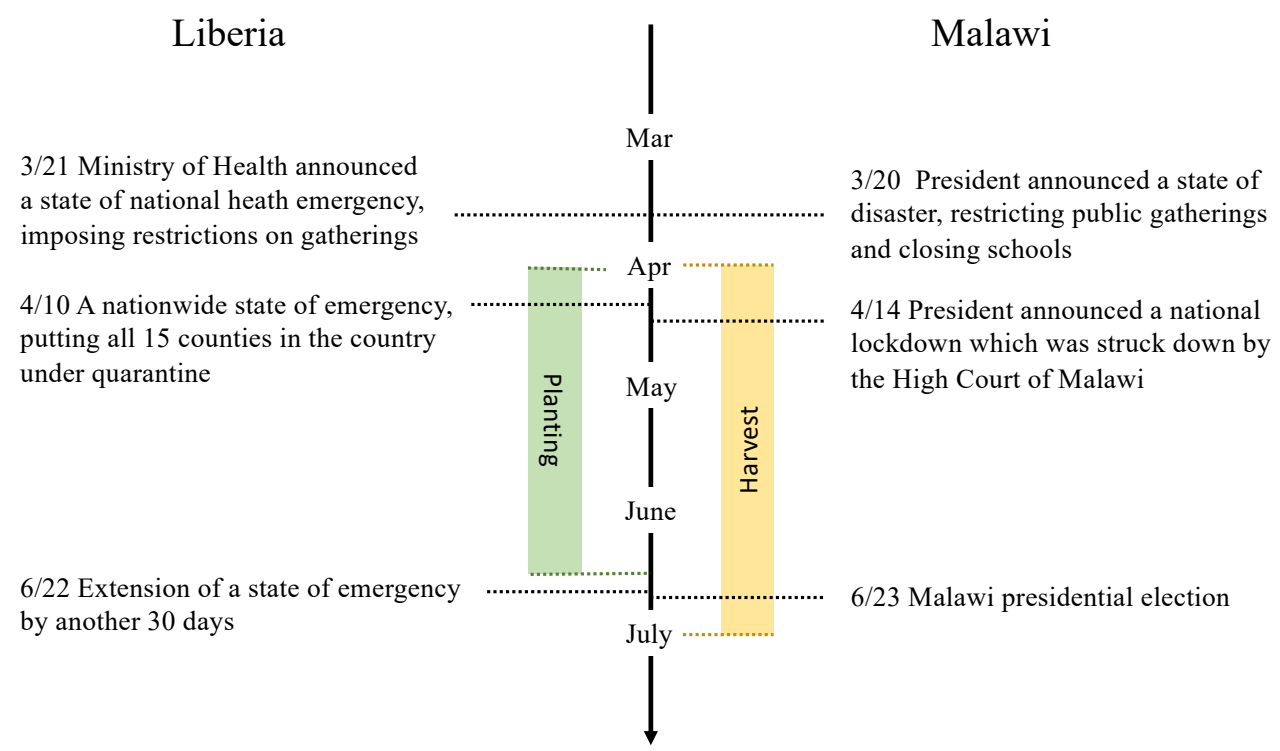

Note: 
Figure A4: Historical Price Trends

\section{Liberia: 2011-2019}
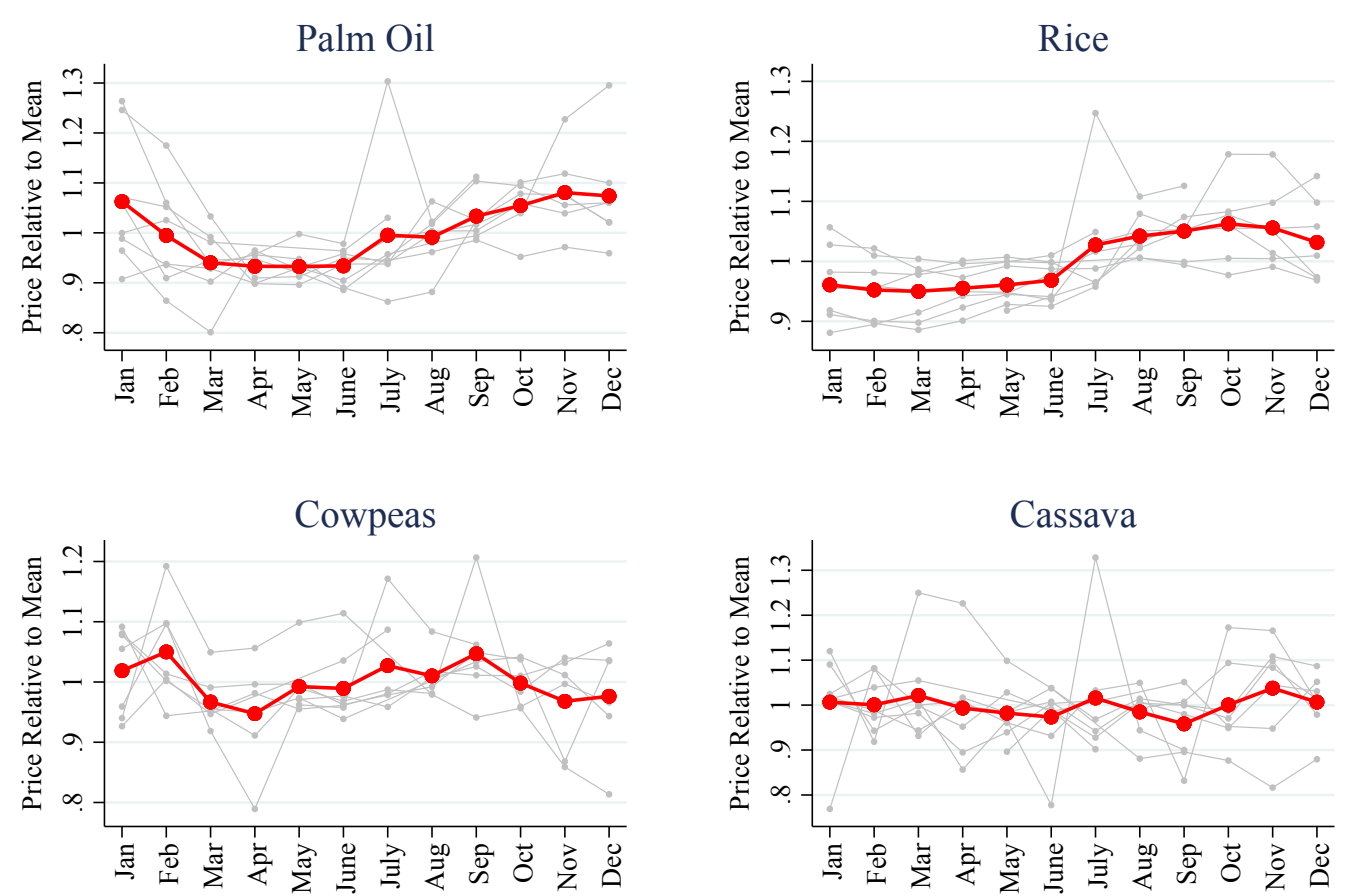

Malawi: 2012-2019
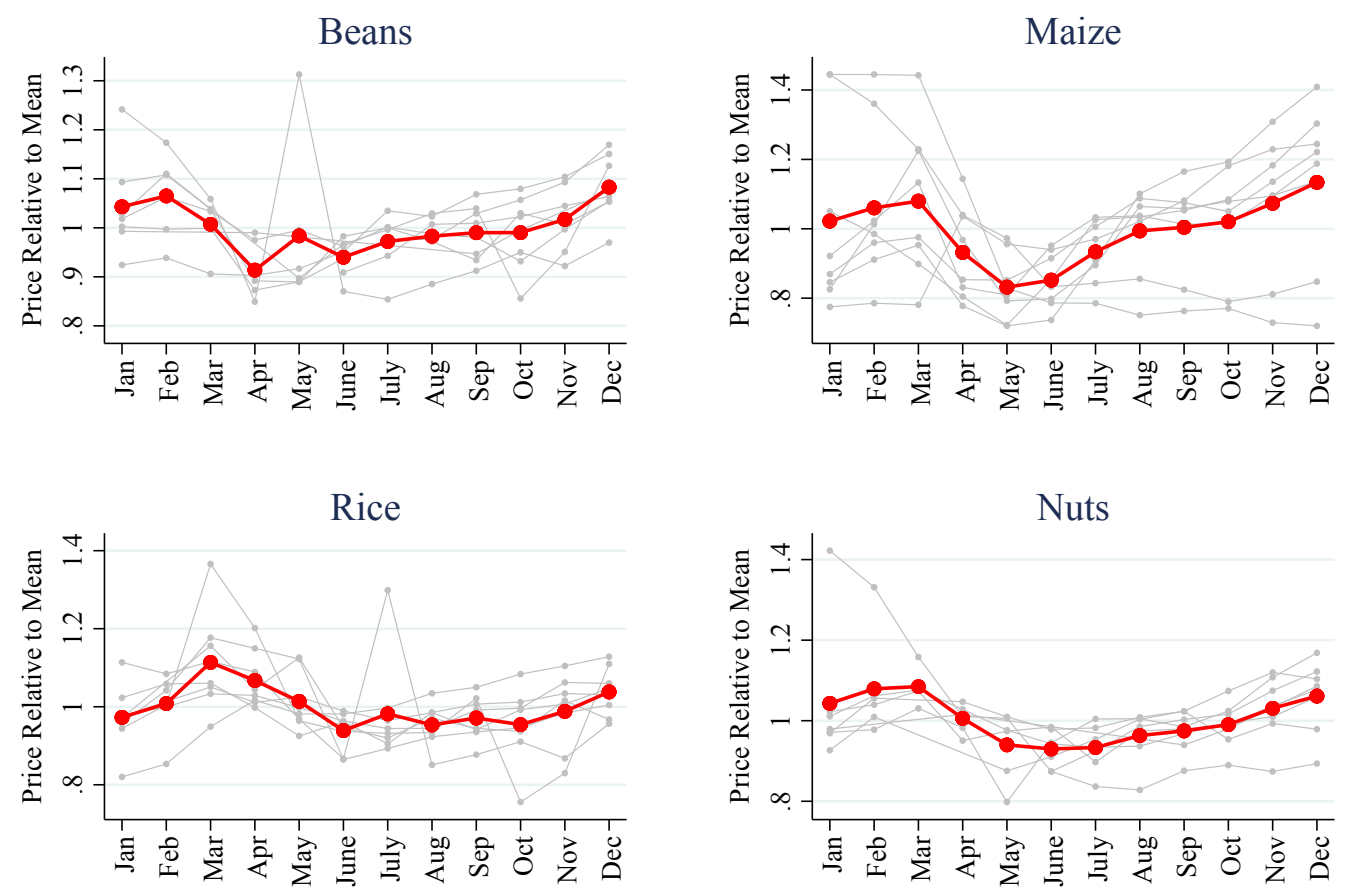

Note: Each grey lines indicate prices for each individual year and red dots show the long run average prices across years in a given month. 
Figure A5: Changes in food security, pre- and post-COVID (by component)
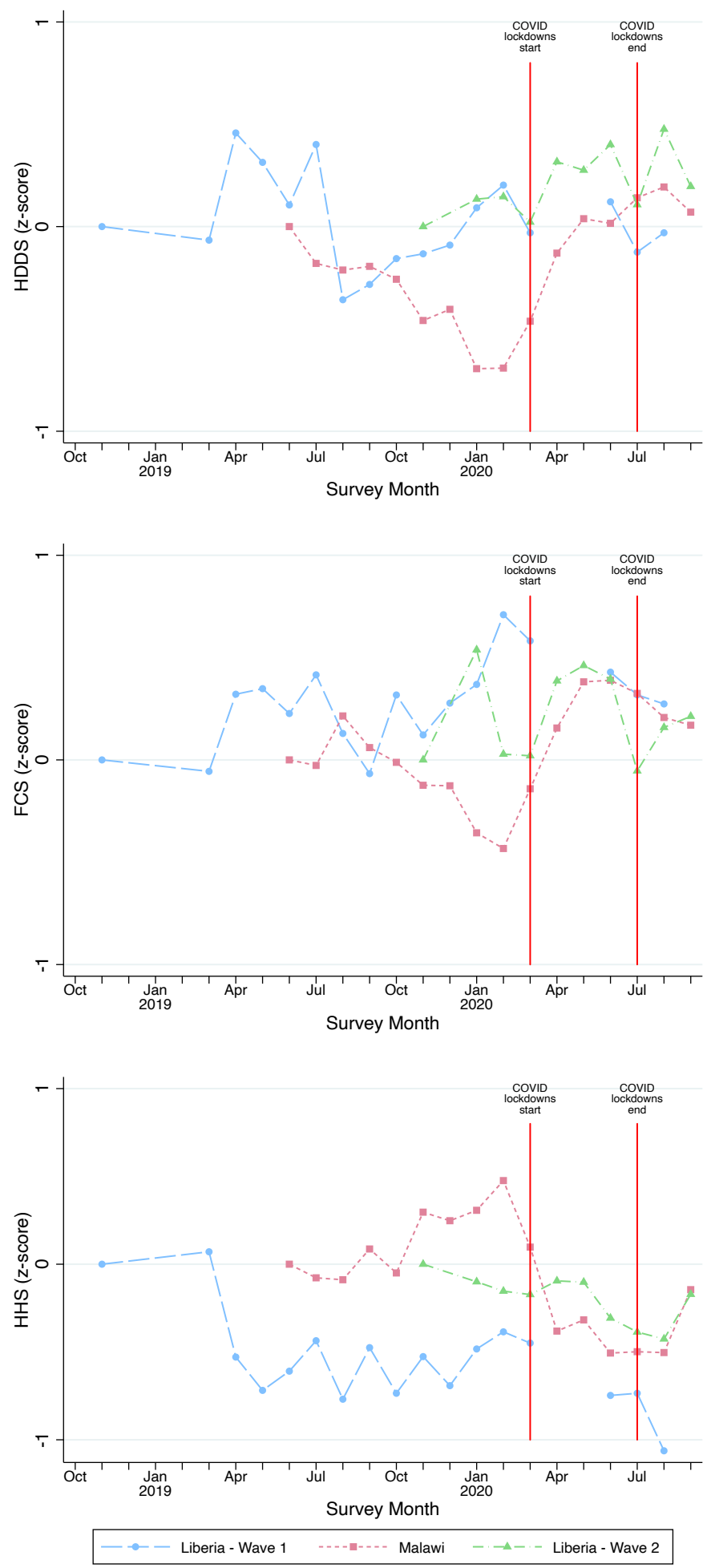

Note: This graph shows the same information as Figure 1, but is broken down into each of the components: (1) the dietary diversity score (HDDS), (2) the food consumption score (FCS), and (3) the household hunger scale HHS). The recall period for these variables is 24 hours for the HDDS and one week for the FCS and HHS. The figure shows the average for the control group only. There are 75 respondents in Liberia Wave 1, 174 in Liberia Wave 2, and 296 in Malawi. 
Figure A6: Food security trends from Malawi IHS4 2016

(a) Food consumption score (FCS)

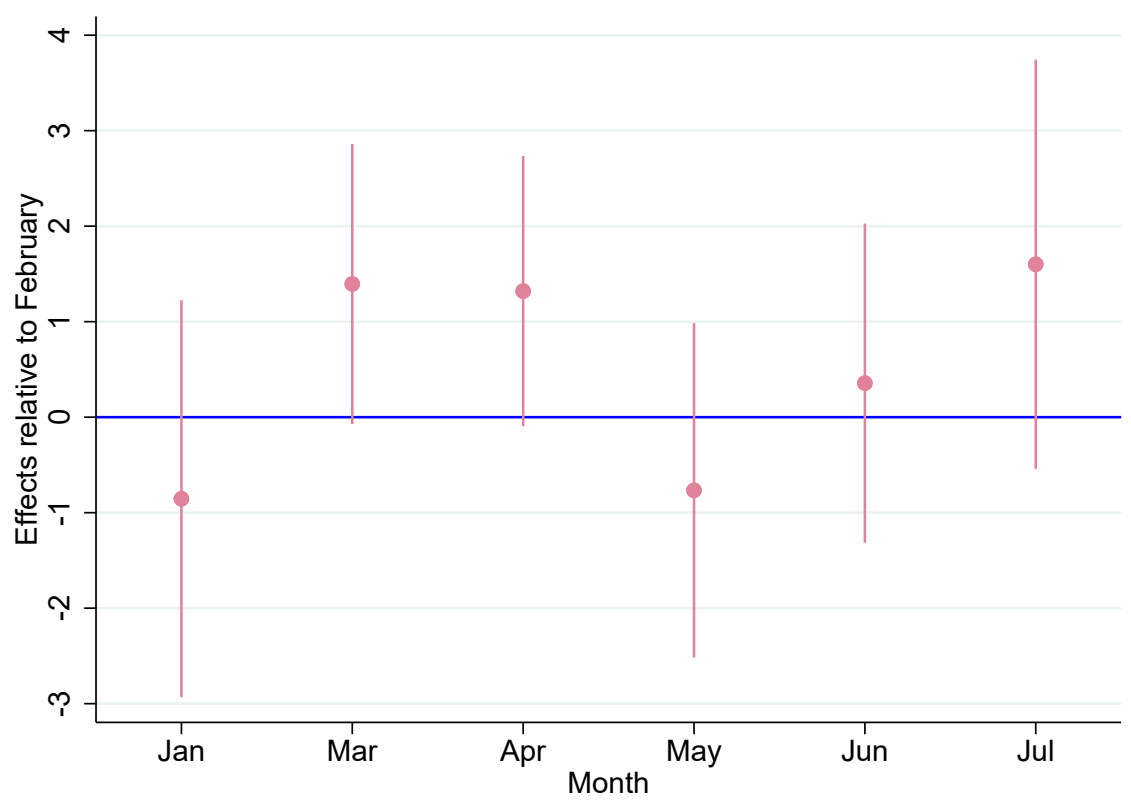

(b) Household hunger scale (HHS)

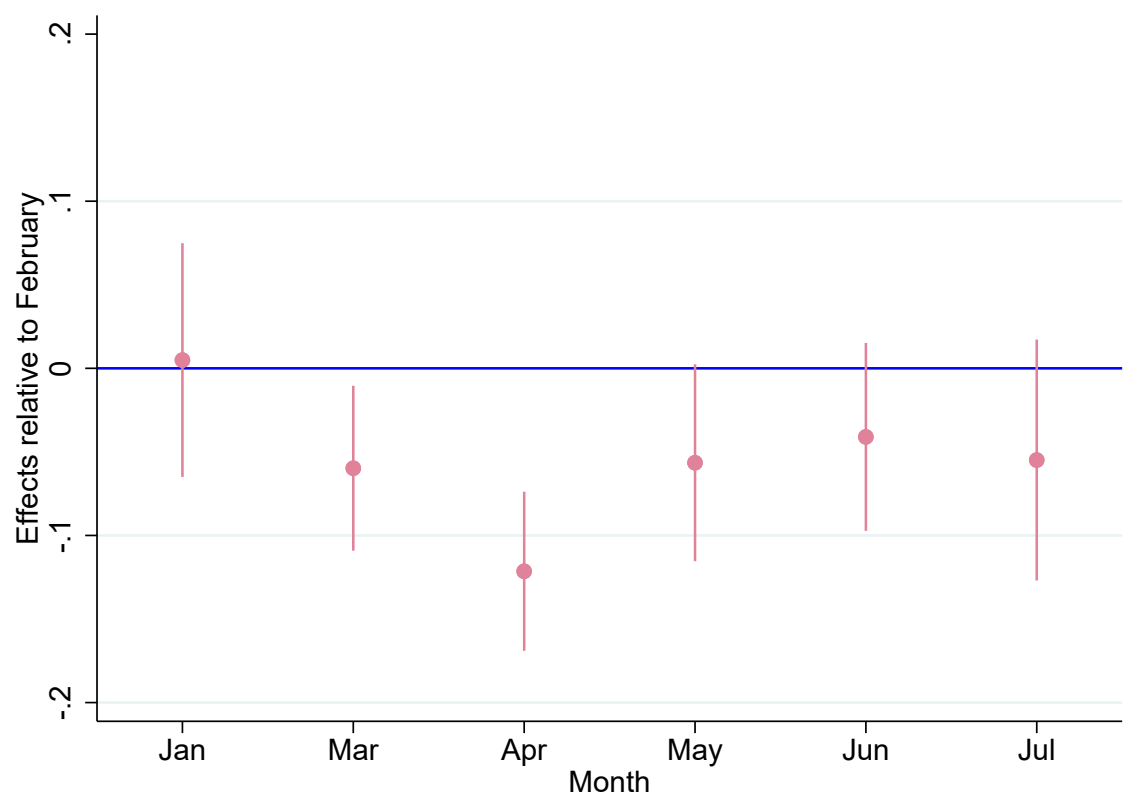

Note: Diplayed are individual months' coefficients relative to February and are for a cross-section of households in the Southern province only. FCS is calculated using the standard definition of FCS while the dependent variable for HHS is a single question "In the past 7 days, did you worry that your HH would not have enough food?" Mean and standard deviation of FCS in February 2016 is 39.0 and 13.5 , while the February average for the outcome in panel (b) is $71 \%$. Note that there was a major drought in 2015-2016 in the country and the government of Malawi declared a countrywide state of disaster in April 2016. 
Figure A7: Food security trends from Malawi IHS2 2010

(a) Food consumption score (FCS)

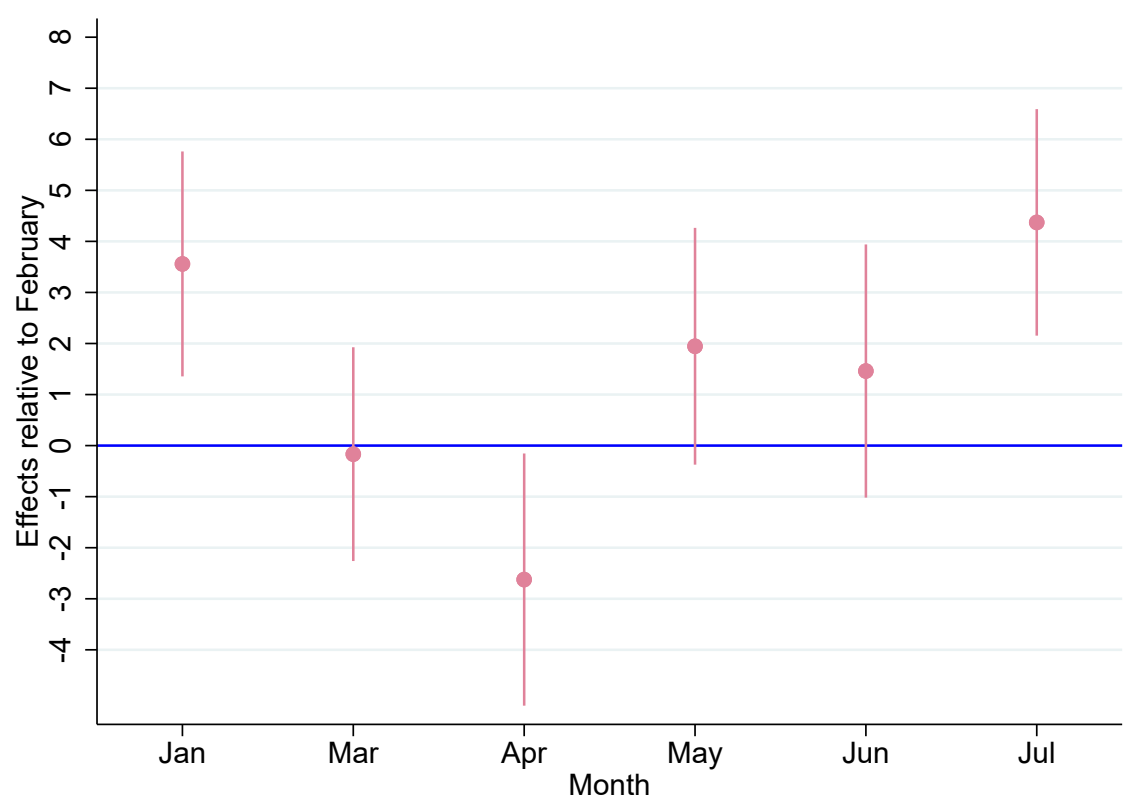

(b) Household hunger scale (HHS)

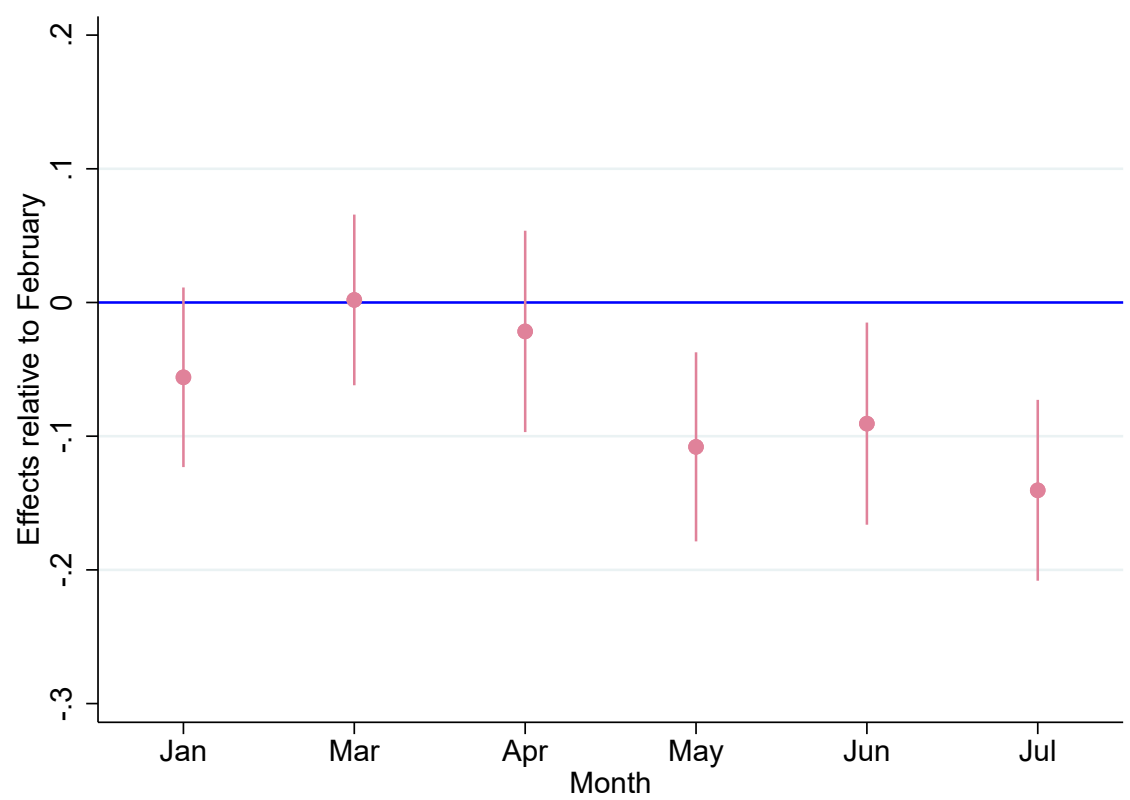

Note: Diplayed are individual months' coefficients relative to February and are for a cross-section of households in the Southern province only. FCS is calculated using the standard definition of FCS while the dependent variable for HHS is a single question "In the past 7 days, did you worry that your HH would not have enough food?" Mean and standard deviation of FCS in February 2016 is 42.3 and 14.4, while the February average for the outcome in panel (b) is $47 \%$. 
Table A1: Household Attrition from Phone Surveys

\begin{tabular}{|c|c|c|c|c|c|c|c|c|c|}
\hline & (1) & $(2)$ & $(3)$ & $(4)$ & $(5)$ & $(6)$ & $(7)$ & \multirow{3}{*}{$\begin{array}{c}(8) \\
\geq 1 \mathrm{R}\end{array}$} & \multirow{3}{*}{$\begin{array}{l}(9) \\
\text { Pct. of } \\
\text { rounds }\end{array}$} \\
\hline & \multicolumn{7}{|c|}{$=1$ if completed survey in following round: } & & \\
\hline & $\mathrm{R} 1$ & $\mathrm{R} 2$ & R3 & $\mathrm{R} 4$ & R5 & R6 & $\mathrm{R} 7$ & & \\
\hline \multicolumn{10}{|c|}{ Panel A: Malawi } \\
\hline GD & $\begin{array}{l}-0.00 \\
(0.01)\end{array}$ & $\begin{array}{l}-0.03 \\
(0.02)\end{array}$ & $\begin{array}{l}-0.03 \\
(0.03)\end{array}$ & $\begin{array}{c}0.02 \\
(0.03)\end{array}$ & $\begin{array}{c}-0.05^{*} \\
(0.03)\end{array}$ & $\begin{array}{l}-0.02 \\
(0.02)\end{array}$ & $\begin{array}{l}-0.01 \\
(0.03)\end{array}$ & & $\begin{array}{l}-0.02 \\
(0.01)\end{array}$ \\
\hline Control Mean & 0.97 & 0.95 & 0.87 & 0.89 & 0.93 & 0.95 & 0.86 & 1.00 & 0.92 \\
\hline Control SD & & & & & & & & & 0.16 \\
\hline Observations & 596 & 596 & 596 & 596 & 596 & 596 & 596 & 596 & 596 \\
\hline \multicolumn{10}{|c|}{ Panel B: Liberia Wave 1} \\
\hline GD & $\begin{array}{l}-0.15^{*} \\
(0.08)\end{array}$ & $\begin{array}{l}-0.15^{*} \\
(0.08)\end{array}$ & $\begin{array}{l}-0.12 \\
(0.08)\end{array}$ & $\begin{array}{l}-0.15^{*} \\
(0.08)\end{array}$ & $\begin{array}{c}-0.16^{* *} \\
(0.08)\end{array}$ & $\begin{array}{l}-0.14^{*} \\
(0.08)\end{array}$ & $\begin{array}{l}-0.08 \\
(0.07)\end{array}$ & $\begin{array}{l}-0.12^{*} \\
(0.07)\end{array}$ & $\begin{array}{c}-0.14^{* *} \\
(0.06)\end{array}$ \\
\hline Control Mean & 0.70 & 0.66 & 0.68 & 0.59 & 0.60 & 0.61 & 0.34 & 0.85 & 0.60 \\
\hline Control SD & & & & & & & & & 0.37 \\
\hline Observations & 172 & 172 & 172 & 172 & 172 & 172 & 172 & 172 & 172 \\
\hline \multicolumn{10}{|c|}{ Panel C: Liberia Wave 2} \\
\hline GD & $\begin{array}{l}-0.02 \\
(0.05)\end{array}$ & $\begin{array}{c}0.00 \\
(0.05)\end{array}$ & $\begin{array}{l}-0.03 \\
(0.05)\end{array}$ & & & & & $\begin{array}{l}-0.04 \\
(0.04)\end{array}$ & $\begin{array}{l}-0.01 \\
(0.04)\end{array}$ \\
\hline Control Mean & 0.75 & 0.67 & 0.69 & & & & & 0.84 & 0.70 \\
\hline Control SD & & & & & & & & & 0.38 \\
\hline Observations & 416 & 416 & 416 & & & & & 416 & 416 \\
\hline
\end{tabular}

Note: Monthly household phone surveys are still ongoing. We include as much data as we have in our analysis, and therefore, round 7 for Malawi sample and round 4 for Liberia wave 2 sample do not include those households who have not been called yet. Column 8 is an indicator for appearing in at least 1 round, while Column 9 is the percentage of rounds that were successfully completed. Regressions include strata fixed effects. 
Table A2: Awareness and Attitudes about COVID-19

(1)

Liberia Malawi

\section{Panel A: Basic awareness}

$=1$ if respondent:

is aware of recent virus outbreak

knows that it's called coronavirus/COVID-19

$0.98 \quad 0.99$

thinks it's a real public health problem

$0.90 \quad 1.00$

$0.95 \quad 0.98$

Panel B: Opinions about government response to COVID

Do you trust the information central gov't is providing?

Do you trust the information local leaders are providing? ${ }^{a}$

$4.37 \quad 4.71$

$=1$ if central gov't and local leaders give different info

$4.39 \quad 4.68$

Do you think gov't measures to prevent spread are helpful? ${ }^{\mathrm{b}}$

$0.05 \quad 0.12$

Do you approve gov't measures? ${ }^{c}$

$4.24 \quad 4.10$

$4.19 \quad 4.09$

Panel C: Support from government/NGO

$=1$ if received cash transfers

0.00

$=1$ if received food support

0.00

Panel D: Concern about COVID contraction

$=1$ if worried or extremely worried about COVID contraction $\quad 0.87 \quad 0.93$

$=1$ if knows anyone who tested for COVID-19 $\quad 0.04 \quad 0.09$

Note:

${ }^{\text {a }}$ 0-5 scale index. 0 - have not received any guidelines; 1 - don't trust at all; 2 - somewhat distrust; 3 - neither trust nor distrust; 4 - somewhat trust; 5 - trust completely.

b 1-5 scale index. 1 - not at all helpful; 2 - not helpful; 3 - neither helpful nor not helpful; 4 - helpful; 5 - very helpful.

c 1-5 scale index. 1 - strongly disapprove; 2 - disapprove; 3 - neither approve nor disapprove; 4 approve; 5 - strongly approve. 
Table A3: Change in Business Outcomes for Food Vendors

\begin{tabular}{|c|c|c|c|c|}
\hline & $\begin{array}{c}(1) \\
\text { No. of } \\
\text { customers } \\
\text { (daily) }\end{array}$ & $\begin{array}{l}\text { Revenue } \\
\text { (monthly) }\end{array}$ & $\begin{array}{c}(3) \\
\text { Profit } \\
\text { (monthly) }\end{array}$ & $\begin{array}{c}(4) \\
\text { Other } \\
\text { income } \\
\text { (monthly) }\end{array}$ \\
\hline \multicolumn{5}{|c|}{ Panel A: Liberia } \\
\hline April & $\begin{array}{c}-14.41^{* * *} \\
(0.79)\end{array}$ & $\begin{array}{c}-102.63^{* * *} \\
(11.51)\end{array}$ & $\begin{array}{c}-24.58^{* * *} \\
(2.43)\end{array}$ & $\begin{array}{c}-5.00^{* *} \\
(2.22)\end{array}$ \\
\hline May & $\begin{array}{c}-12.19^{* * *} \\
(0.92)\end{array}$ & $\begin{array}{c}-104.37^{* * *} \\
(20.34)\end{array}$ & $\begin{array}{c}-18.96^{* * *} \\
(3.88)\end{array}$ & $\begin{array}{l}-3.20 \\
(2.43)\end{array}$ \\
\hline June & $\begin{array}{c}-10.20^{* * *} \\
(1.11)\end{array}$ & $\begin{array}{c}-89.28^{* * *} \\
(23.73)\end{array}$ & $\begin{array}{c}-14.09^{* * *} \\
(4.52)\end{array}$ & $\begin{array}{l}-1.70 \\
(2.47)\end{array}$ \\
\hline February mean & 31.64 & 258.37 & 47.48 & 8.11 \\
\hline February SD & 21.42 & 406.32 & 69.41 & 56.11 \\
\hline F statistic & 114.76 & 30.93 & 41.00 & 3.39 \\
\hline Observations & 2,199 & 2,199 & 2,199 & 2,199 \\
\hline No. of vendors & 676 & 676 & 676 & 676 \\
\hline \multicolumn{5}{|c|}{ Panel B: Malawi } \\
\hline April & $\begin{array}{c}-22.12^{* * *} \\
(1.64)\end{array}$ & $\begin{array}{c}-182.01^{* * *} \\
(30.12)\end{array}$ & $\begin{array}{c}-44.34^{* * *} \\
(4.92)\end{array}$ & $\begin{array}{c}-17.50 * * * \\
(6.23)\end{array}$ \\
\hline May & $\begin{array}{c}-23.80^{* * *} \\
(2.44)\end{array}$ & $\begin{array}{c}-136.60^{* * *} \\
(50.38)\end{array}$ & $\begin{array}{c}-32.20^{* * *} \\
(6.82)\end{array}$ & $\begin{array}{c}2.64 \\
(8.46)\end{array}$ \\
\hline June & $\begin{array}{c}-24.89^{* * *} \\
(2.40)\end{array}$ & $\begin{array}{c}-118.68^{* *} \\
(48.05)\end{array}$ & $\begin{array}{c}-21.75^{* * *} \\
(7.68)\end{array}$ & $\begin{array}{c}3.40 \\
(6.86)\end{array}$ \\
\hline February mean & 67.68 & 592.57 & 103.59 & 34.80 \\
\hline February SD & 73.82 & 1276.22 & 196.02 & 188.23 \\
\hline F statistic & 61.55 & 12.73 & 28.48 & 5.95 \\
\hline Observations & 3,813 & 3,813 & 3,813 & 3,813 \\
\hline No. of vendors & 1,042 & 1,042 & 1,042 & 1,042 \\
\hline
\end{tabular}

Note: All variables are Winsorized at 99\%. All monetary values are in USD. Standard errors are clustered at the market level. 
Table A4: Changes in Prices of Soap and Cleaning Products

\begin{tabular}{|c|c|c|c|c|c|c|c|}
\hline & $(1)$ & $(2)$ & $(3)$ & (4) & $(5)$ & $(6)$ & $(7)$ \\
\hline & \multicolumn{4}{|c|}{ Liberia } & \multicolumn{3}{|c|}{ Malawi } \\
\hline & Soap $^{a}$ & Detergent $^{\mathrm{b}}$ & Disinfectant $^{\mathrm{c}}$ & $\begin{array}{l}\text { Water } \\
\text { bucket }^{\mathrm{d}}\end{array}$ & Soap $^{\mathrm{a}}$ & Detergent $^{\mathrm{b}}$ & $\begin{array}{l}\text { Water } \\
\text { bucket }^{\mathrm{d}}\end{array}$ \\
\hline May & $\begin{array}{c}0.05 * * * \\
(0.00)\end{array}$ & $\begin{array}{c}0.02^{* * *} \\
(0.00)\end{array}$ & $\begin{array}{c}0.24^{* * *} \\
(0.01)\end{array}$ & $\begin{array}{c}1.05 * * * \\
(0.15)\end{array}$ & $\begin{array}{c}0.00 \\
(0.00)\end{array}$ & $\begin{array}{c}0.02^{* * *} \\
(0.00)\end{array}$ & $\begin{array}{c}0.51^{* * *} \\
(0.06)\end{array}$ \\
\hline February Mean & 0.18 & 0.36 & 0.85 & 2.22 & 0.18 & 0.36 & 2.22 \\
\hline February SD & 0.08 & 0.29 & 0.31 & 1.43 & 0.08 & 0.29 & 1.43 \\
\hline Number of markets & 80 & 80 & 80 & 74 & 94 & 95 & 86 \\
\hline Number of vendors & 567 & 568 & 415 & 300 & 808 & 789 & 594 \\
\hline Observations & 1,129 & 1,125 & 794 & 544 & 1,614 & 1,574 & 1,152 \\
\hline
\end{tabular}

Note: All prices are in USD. Regressions include market fixed effects. Standard errors are clustered at market level and reported in parentheses. All variables are Winsorized at $99 \%$.

${ }^{\text {a }}$ A bar or piece of soap.

${ }^{\mathrm{b}}$ A small pack of detergent powder.

${ }^{\mathrm{c}}$ A $100 \mathrm{ml}$ bottle of disinfectant alcohol.

d A medium-sized plastic water bucket. 
Table A5: Household Food Security and Expenditures (in Regressions)

\begin{tabular}{|c|c|c|c|c|c|c|}
\hline & $(1)$ & $(2)$ & $(3)$ & $(4)$ & $(5)$ & $(6)$ \\
\hline & \multicolumn{4}{|c|}{ Food consumption } & \multirow[b]{2}{*}{$\begin{array}{c}\text { Food } \\
\text { Expenditure } \\
\text { (monthly) }\end{array}$} & \multirow[b]{2}{*}{$\begin{array}{c}\text { Total } \\
\text { Expenditure } \\
\text { (monthly) }\end{array}$} \\
\hline & $\mathrm{HDDS}^{\mathrm{a}}$ & $\mathrm{FCS}^{\mathrm{b}}$ & $\mathrm{HHS}^{\mathrm{c}}$ & $\begin{array}{c}\text { Food } \\
\text { Security } \\
\text { Index }^{\mathrm{d}}\end{array}$ & & \\
\hline \multicolumn{7}{|l|}{ Panel A: Liberia } \\
\hline April & $\begin{array}{c}0.28 \\
(0.18)\end{array}$ & $\begin{array}{c}3.58 * * * \\
(1.39)\end{array}$ & $\begin{array}{l}-0.05 \\
(0.10)\end{array}$ & $\begin{array}{c}0.21^{* *} \\
(0.09)\end{array}$ & $\begin{array}{c}0.91 \\
(1.67)\end{array}$ & $\begin{array}{l}-4.94 \\
(4.69)\end{array}$ \\
\hline May & $\begin{array}{c}0.62^{* * *} \\
(0.17)\end{array}$ & $\begin{array}{c}-0.13 \\
(1.36)\end{array}$ & $\begin{array}{c}-0.16^{*} \\
(0.09)\end{array}$ & $\begin{array}{c}0.24^{* * *} \\
(0.09)\end{array}$ & $\begin{array}{c}-3.57^{* *} \\
(1.64)\end{array}$ & $\begin{array}{c}-7.62^{*} \\
(4.61)\end{array}$ \\
\hline June & $\begin{array}{c}0.63^{* * *} \\
(0.17)\end{array}$ & $\begin{array}{c}5.29 * * * \\
(1.36)\end{array}$ & $\begin{array}{c}-0.24^{* *} \\
(0.09)\end{array}$ & $\begin{array}{c}0.44^{* * *} \\
(0.09)\end{array}$ & $\begin{array}{c}1.06 \\
(1.64)\end{array}$ & $\begin{array}{c}11.31^{* *} \\
(4.60)\end{array}$ \\
\hline July & $\begin{array}{c}0.31 \\
(0.19)\end{array}$ & $\begin{array}{c}-4.06^{* * *} \\
(1.49)\end{array}$ & $\begin{array}{c}-0.48^{* * *} \\
(0.10)\end{array}$ & $\begin{array}{c}0.20^{* *} \\
(0.10)\end{array}$ & $\begin{array}{l}-0.14 \\
(1.79)\end{array}$ & $\begin{array}{c}-26.45^{* * *} \\
(5.05)\end{array}$ \\
\hline August & $\begin{array}{l}0.32^{*} \\
(0.19)\end{array}$ & $\begin{array}{c}2.00 \\
(1.45)\end{array}$ & $\begin{array}{c}-0.23^{* *} \\
(0.10)\end{array}$ & $\begin{array}{c}0.26 * * * \\
(0.09)\end{array}$ & $\begin{array}{l}-1.24 \\
(1.75)\end{array}$ & $\begin{array}{l}-2.15 \\
(4.92)\end{array}$ \\
\hline September & $\begin{array}{c}0.22 \\
(0.20)\end{array}$ & $\begin{array}{c}-5.20^{* * *} \\
(1.52)\end{array}$ & $\begin{array}{l}-0.20^{*} \\
(0.11)\end{array}$ & $\begin{array}{c}0.00 \\
(0.10)\end{array}$ & $\begin{array}{c}-4.24^{* *} \\
(1.83)\end{array}$ & $\begin{array}{c}-37.23 * * * \\
(5.15)\end{array}$ \\
\hline 2020 pre-lockdown mean & 6.18 & 55.74 & 0.78 & 0.00 & 28.86 & 68.49 \\
\hline 2020 pre-lockdown SD & 1.77 & 15.53 & 0.92 & 1.00 & 19.55 & 56.84 \\
\hline F statistic & 2.09 & 2.78 & 1.70 & 2.73 & 2.46 & 3.26 \\
\hline Observations & 1,061 & 1,061 & 1,061 & 1,061 & 1,061 & 1,061 \\
\hline No. of households & 308 & 308 & 308 & 308 & 308 & 308 \\
\hline \multicolumn{7}{|l|}{ Panel B: Malawi } \\
\hline April & $\begin{array}{c}0.69^{* * *} \\
(0.10)\end{array}$ & $\begin{array}{c}6.45^{* * *} \\
(0.83)\end{array}$ & $\begin{array}{c}-1.06^{* * *} \\
(0.07)\end{array}$ & $\begin{array}{c}0.72^{* * *} \\
(0.05)\end{array}$ & $\begin{array}{c}-9.20 * * * \\
(1.02)\end{array}$ & $\begin{array}{c}-10.96^{* * *} \\
(2.74)\end{array}$ \\
\hline May & $\begin{array}{c}1.06 * * * \\
(0.10)\end{array}$ & $\begin{array}{c}7.93^{* * *} \\
(0.85)\end{array}$ & $\begin{array}{c}-0.73^{* * *} \\
(0.07)\end{array}$ & $\begin{array}{c}0.73^{* * *} \\
(0.05)\end{array}$ & $\begin{array}{c}-8.09^{* * *} \\
(1.03)\end{array}$ & $\begin{array}{c}-5.12^{*} \\
(2.78)\end{array}$ \\
\hline June & $\begin{array}{c}0.96^{* * *} \\
(0.10)\end{array}$ & $\begin{array}{c}9.44^{* * *} \\
(0.81)\end{array}$ & $\begin{array}{c}-1.17^{* * *} \\
(0.07)\end{array}$ & $\begin{array}{c}0.90^{* * *} \\
(0.05)\end{array}$ & $\begin{array}{c}-9.28^{* * *} \\
(1.00)\end{array}$ & $\begin{array}{c}7.15^{* * *} \\
(2.68)\end{array}$ \\
\hline July & $\begin{array}{c}1.28^{* * *} \\
(0.10)\end{array}$ & $\begin{array}{c}8.22^{* * *} \\
(0.83)\end{array}$ & $\begin{array}{c}-0.99 * * * \\
(0.07)\end{array}$ & $\begin{array}{c}0.89 * * * \\
(0.05)\end{array}$ & $\begin{array}{c}-8.22^{* * *} \\
(1.02)\end{array}$ & $\begin{array}{c}-10.40^{* * *} \\
(2.73)\end{array}$ \\
\hline August & $\begin{array}{c}1.21^{* * *} \\
(0.10)\end{array}$ & $\begin{array}{c}7.27 * * * \\
(0.83)\end{array}$ & $\begin{array}{c}-1.18^{* * *} \\
(0.07)\end{array}$ & $\begin{array}{c}0.91^{* * *} \\
(0.05)\end{array}$ & $\begin{array}{c}-8.37^{* * *} \\
(1.02)\end{array}$ & $\begin{array}{l}-4.17 \\
(2.74)\end{array}$ \\
\hline September & $\begin{array}{c}1.12^{* * *} \\
(0.11)\end{array}$ & $\begin{array}{c}5.41^{* * *} \\
(0.94)\end{array}$ & $\begin{array}{c}-0.53^{* * *} \\
(0.08)\end{array}$ & $\begin{array}{c}0.61^{* * *} \\
(0.06)\end{array}$ & $\begin{array}{c}-7.81^{* * *} \\
(1.15)\end{array}$ & $\begin{array}{c}-14.78^{* * *} \\
(3.10)\end{array}$ \\
\hline 2020 pre-lockdown mean & 4.66 & 43.17 & 1.57 & -0.00 & 23.20 & 43.93 \\
\hline 2020 pre-lockdown SD & 1.62 & 15.43 & 1.15 & 1.00 & 17.84 & 37.69 \\
\hline F statistic & 4.60 & 5.83 & 3.71 & 6.62 & 3.34 & 3.05 \\
\hline Observations & 2,115 & 2,115 & 2,115 & 2,115 & 2,115 & 2,115 \\
\hline No. of households & 538 & 538 & 538 & 538 & 538 & 538 \\
\hline
\end{tabular}

Note: Sample from household phone survey for January - September 2020, excluding surveys conducted in March 2020, because it was a month that was partially both pre- and post-COVID. Omitted group in the regressions is for the last survey round before COVID (January and February 2020 pooled). Regressions include survey month fixed effects, and individual fixed effects. In Panel A, sample includes only Wave 2. All monetary values in USD and Winsorized at $99 \%$.

${ }^{a}$ Household dietary diversity score (HDDS) ranges from 0 (less diverse) to 12 (more diverse).

${ }^{\mathrm{b}}$ Food consumption score (FCS) ranges from 0 (worse) to 112 (better).

${ }^{\mathrm{c}}$ Household hunger scale (HHS) ranges from 0 (less severe) to 6 (more severe).

d Re-standardized z-score of HDDS, FCS, and HHS (negatively weighted). Z-score of each of HDDS, FCS, and HHS (negatively weighted) are summed up, and this variable is standardized again by using its mean and standard deviation of pooled data from January and February 2020. 
Table A6: Cash Effects on Food Security (Lee bounds for Liberia Wave 1)

\begin{tabular}{|c|c|c|c|c|c|c|c|c|c|}
\hline & $(1)$ & $(2)$ & $(3)$ & $(4)$ & $(5)$ & $(6)$ & $(7)$ & $(8)$ & $(9)$ \\
\hline & \multicolumn{3}{|c|}{$\mathrm{HDDS}^{\mathrm{a}}$} & \multicolumn{3}{|c|}{$\mathrm{FCS}^{\mathrm{b}}$} & \multicolumn{3}{|c|}{$\mathrm{HHS}^{\mathrm{c}}$} \\
\hline & Baseline & $\begin{array}{l}\text { Lower } \\
\text { Bound }\end{array}$ & $\begin{array}{l}\text { Upper } \\
\text { Bound }\end{array}$ & Baseline & $\begin{array}{l}\text { Lower } \\
\text { Bound }\end{array}$ & $\begin{array}{l}\text { Upper } \\
\text { Bound }\end{array}$ & Baseline & $\begin{array}{l}\text { Lower } \\
\text { Bound }\end{array}$ & $\begin{array}{l}\text { Upper } \\
\text { Bound }\end{array}$ \\
\hline GD & $\begin{array}{c}0.47^{* * *} \\
(0.18)\end{array}$ & $\begin{array}{l}-0.12 \\
(0.17)\end{array}$ & $\begin{array}{c}1.09 * * * \\
(0.15)\end{array}$ & $\begin{array}{c}5.99 * * * \\
(1.83)\end{array}$ & $\begin{array}{c}0.45 \\
(1.65)\end{array}$ & $\begin{array}{c}12.13^{* * *} \\
(1.41)\end{array}$ & $\begin{array}{c}-0.26^{* *} \\
(0.11)\end{array}$ & $\begin{array}{c}0.27^{* * *} \\
(0.09)\end{array}$ & $\begin{array}{c}-0.71^{* * *} \\
(0.11)\end{array}$ \\
\hline Control Mean & 5.64 & 6.24 & 5.01 & 45.58 & 51.86 & 39.29 & 0.99 & 0.44 & 1.39 \\
\hline Control SD & 1.58 & 1.24 & 1.18 & 14.00 & 10.23 & 10.91 & 1.06 & 0.58 & 1.01 \\
\hline \multirow[t]{4}{*}{ Observations } & 646 & 553 & 556 & 646 & 546 & 538 & 646 & 540 & 536 \\
\hline & $(10)$ & $(11)$ & $(12)$ & (13) & $(14)$ & $(15)$ & & & \\
\hline & \multicolumn{3}{|c|}{ Food Security Index ${ }^{\mathrm{d}}$} & \multicolumn{3}{|c|}{ Food Expenditure } & & & \\
\hline & Baseline & $\begin{array}{l}\text { Lower } \\
\text { Bound }\end{array}$ & $\begin{array}{l}\text { Upper } \\
\text { Bound }\end{array}$ & Baseline & $\begin{array}{l}\text { Lower } \\
\text { Bound }\end{array}$ & $\begin{array}{l}\text { Upper } \\
\text { Bound }\end{array}$ & & & \\
\hline GD & $\begin{array}{c}0.36^{* * *} \\
(0.10)\end{array}$ & $\begin{array}{c}0.04 \\
(0.09)\end{array}$ & $\begin{array}{c}0.69^{* * *} \\
(0.08)\end{array}$ & $\begin{array}{l}3.05^{*} \\
(1.57)\end{array}$ & $\begin{array}{c}0.64 \\
(1.42)\end{array}$ & $\begin{array}{c}6.15^{* * *} \\
(1.23)\end{array}$ & & & \\
\hline Control Mean & 0.40 & 0.75 & 0.06 & 10.32 & 10.72 & 5.34 & & & \\
\hline Control SD & 0.77 & 0.53 & 0.61 & 16.06 & 16.91 & 9.26 & & & \\
\hline Observations & 646 & 547 & 540 & 646 & 606 & 587 & & & \\
\hline
\end{tabular}

Note: Regressions include survey month fixed effects, strata fixed effects, and baseline measurements. Standard errors are clustered at village level. Sample includes 135 households in Liberia Wave 1 during whole period of data collection (March 2019 - August 2020).

${ }^{\text {a }}$ Household dietary diversity score (HDDS) ranges from 0 (less diverse) to 12 (more diverse).

b Food consumption score (FCS) ranges from 0 (worse) to 112 (better).

${ }^{\mathrm{c}}$ Household hunger scale (HHS) ranges from 0 (less severe) to 6 (more severe).

d Standardized z-score of HDDS, FCS, and HHS (negatively weighted), using means and standard deviations from control group at baseline (Nov-Dec 2018). 
Table A7: Cash Effects on Food Security (Liberia Wave 2)

\begin{tabular}{|c|c|c|c|c|c|}
\hline & $\mathrm{HDDS}^{\mathrm{a}}$ & $\mathrm{FCS}^{\mathrm{b}}$ & $\mathrm{HHS}^{\mathrm{c}}$ & $\begin{array}{c}(4) \\
\text { Food } \\
\text { Security } \\
\text { Index }^{\mathrm{d}}\end{array}$ & $\begin{array}{c}\text { Food } \\
\text { Expenditure }\end{array}$ \\
\hline \multicolumn{6}{|l|}{ ITT: } \\
\hline GD treatment assignment & $\begin{array}{c}0.05 \\
(0.15)\end{array}$ & $\begin{array}{l}-0.70 \\
(1.26)\end{array}$ & $\begin{array}{l}-0.11 \\
(0.08)\end{array}$ & $\begin{array}{c}0.07 \\
(0.10)\end{array}$ & $\begin{array}{l}-1.11 \\
(1.71)\end{array}$ \\
\hline \multicolumn{6}{|l|}{ TOT: } \\
\hline GD first payment & $\begin{array}{c}0.12 \\
(0.36)\end{array}$ & $\begin{array}{l}-1.67 \\
(3.02)\end{array}$ & $\begin{array}{l}-0.26 \\
(0.17)\end{array}$ & $\begin{array}{c}0.16 \\
(0.22)\end{array}$ & $\begin{array}{l}-2.66 \\
(4.10)\end{array}$ \\
\hline $\begin{array}{l}\text { Control Mean } \\
\text { Control SD } \\
\text { Observations }\end{array}$ & $\begin{array}{l}6.57 \\
1.58 \\
688\end{array}$ & $\begin{array}{c}55.90 \\
14.06 \\
688\end{array}$ & $\begin{array}{l}0.58 \\
0.88 \\
688\end{array}$ & $\begin{array}{l}0.30 \\
0.95 \\
688\end{array}$ & $\begin{array}{c}29.08 \\
17.00 \\
688\end{array}$ \\
\hline \multicolumn{6}{|c|}{$\begin{array}{l}\text { Note: Sample includes } 256 \text { households in Liberia Wave } 2 \text { during the period of March- } \\
\text { August } 2020 \text {, excluding two districts (Buu Yao and Leewehpea Mahn in Nimba district) } \\
\text { where no village received any transfers by that time. Regressions include survey month } \\
\text { fixed effects, strata fixed effects, and baseline measurements. Standard errors are clus- } \\
\text { tered at village level. } \\
\text { a Household dietary diversity score (HDDS) ranges from } 0 \text { (less diverse) to } 12 \text { (more di- } \\
\text { verse). } \\
\text { b Food consumption score (FCS) ranges from } 0 \text { (worse) to } 112 \text { (better). } \\
{ }^{c} \text { Household hunger scale (HHS) ranges from } 0 \text { (less severe) to } 6 \text { (more severe). } \\
\text { d Standardized z-score of HDDS, FCS, and HHS (negatively weighted), using means and } \\
\text { standard deviations from control group in March } 2020 \text {. }\end{array}$} \\
\hline
\end{tabular}


Table A8: Income, pre- and post-COVID

\begin{tabular}{|c|c|c|c|c|c|c|}
\hline & \multicolumn{3}{|c|}{ Respondent (panel) $)^{\mathrm{a}}$} & \multicolumn{3}{|c|}{ Household (retrospective) ${ }^{b}$} \\
\hline & $\begin{array}{c}(1) \\
\text { Casual labor } \\
\text { income }\end{array}$ & $\begin{array}{c}\text { (2) } \\
\text { Business } \\
\text { profit }\end{array}$ & $\begin{array}{c}(3) \\
\text { Other } \\
\text { income }\end{array}$ & $\begin{array}{c}(4) \\
\text { Casual labor } \\
\text { income }\end{array}$ & $\begin{array}{c}(5) \\
\text { Business } \\
\text { profit }\end{array}$ & $\begin{array}{c}(6) \\
\text { Other } \\
\text { income }\end{array}$ \\
\hline \multicolumn{7}{|l|}{ Panel A: Liberia } \\
\hline April & $\begin{array}{c}0.01 \\
(0.69)\end{array}$ & $\begin{array}{c}0.98 \\
(0.95)\end{array}$ & $\begin{array}{c}6.06^{* * *} \\
(2.21)\end{array}$ & $\begin{array}{c}0.92^{* * *} \\
(0.34)\end{array}$ & $\begin{array}{c}0.98 \\
(0.60)\end{array}$ & $\begin{array}{c}1.36 \\
(1.73)\end{array}$ \\
\hline May & $\begin{array}{c}-1.27^{*} \\
(0.68)\end{array}$ & $\begin{array}{c}-3.82^{* * *} \\
(0.93)\end{array}$ & $\begin{array}{l}4.11^{*} \\
(2.18)\end{array}$ & $\begin{array}{l}0.65^{*} \\
(0.34)\end{array}$ & $\begin{array}{l}-0.46 \\
(0.60)\end{array}$ & $\begin{array}{l}-1.37 \\
(1.73)\end{array}$ \\
\hline June & $\begin{array}{l}-0.00 \\
(0.68)\end{array}$ & $\begin{array}{c}0.37 \\
(0.93)\end{array}$ & $\begin{array}{c}0.37 \\
(2.18)\end{array}$ & $\begin{array}{c}-1.53^{* * *} \\
(0.34)\end{array}$ & $\begin{array}{c}-1.10^{*} \\
(0.60)\end{array}$ & $\begin{array}{c}-5.66^{* * *} \\
(1.73)\end{array}$ \\
\hline July & $\begin{array}{c}-1.66^{* *} \\
(0.79)\end{array}$ & $\begin{array}{c}-3.40 * * * \\
(1.08)\end{array}$ & $\begin{array}{c}1.43 \\
(2.52)\end{array}$ & & & \\
\hline 2020 pre-lockdown mean & 1.89 & 3.51 & 1.76 & 1.53 & 2.05 & 5.66 \\
\hline 2020 pre-lockdown SD & 7.92 & 11.92 & 9.63 & 3.62 & 7.11 & 31.77 \\
\hline F statistic & 1.22 & 2.13 & 1.26 & 3.80 & 1.99 & 2.28 \\
\hline Observations & 823 & 823 & 823 & 840 & 840 & 840 \\
\hline No. of respondents & 370 & 370 & 370 & 370 & 370 & 370 \\
\hline \multicolumn{7}{|l|}{ Panel B: Malawi } \\
\hline April & $\begin{array}{c}-3.42^{* * *} \\
(0.56)\end{array}$ & $\begin{array}{l}-0.02 \\
(0.44)\end{array}$ & $\begin{array}{l}-0.03 \\
(0.24)\end{array}$ & $\begin{array}{c}0.08 \\
(0.67)\end{array}$ & $\begin{array}{c}0.40 \\
(0.38)\end{array}$ & $\begin{array}{c}0.30 \\
(0.41)\end{array}$ \\
\hline May & $\begin{array}{c}-1.77^{* * *} \\
(0.57)\end{array}$ & $\begin{array}{l}-0.72 \\
(0.45)\end{array}$ & $\begin{array}{l}-0.14 \\
(0.25)\end{array}$ & $\begin{array}{c}1.84^{* * *} \\
(0.67)\end{array}$ & $\begin{array}{c}0.24 \\
(0.38)\end{array}$ & $\begin{array}{c}0.61 \\
(0.41)\end{array}$ \\
\hline June & $\begin{array}{c}-2.89 * * * \\
(0.55)\end{array}$ & $\begin{array}{l}-0.27 \\
(0.43)\end{array}$ & $\begin{array}{c}0.22 \\
(0.24)\end{array}$ & $\begin{array}{c}2.31^{* * *} \\
(0.67)\end{array}$ & $\begin{array}{c}0.38 \\
(0.38)\end{array}$ & $\begin{array}{c}0.16 \\
(0.41)\end{array}$ \\
\hline July & $\begin{array}{c}-1.75^{* * *} \\
(0.58)\end{array}$ & $\begin{array}{c}-0.78^{*} \\
(0.45)\end{array}$ & $\begin{array}{l}-0.03 \\
(0.25)\end{array}$ & & & \\
\hline 2020 pre-lockdown mean & 5.86 & 1.70 & 0.37 & 2.24 & 0.74 & 1.01 \\
\hline 2020 pre-lockdown SD & 9.68 & 8.19 & 3.57 & 5.28 & 5.49 & 7.67 \\
\hline F statistic & 2.43 & 2.27 & 1.80 & 1.08 & 1.69 & 4.61 \\
\hline Observations & 1,624 & 1,624 & 1,624 & 1,468 & 1,468 & 1,468 \\
\hline No. of respondents & 583 & 583 & 583 & 583 & 583 & 583 \\
\hline $\begin{array}{l}\text { Note: Variables are measured } \\
\text { dents were called every } 2 \text { mon } \\
\text { The March } 2020 \text { observations } \\
\text { Regressions include survey m } \\
\text { coverage over this time perioc } \\
\text { centile. } \\
\text { a Income information for prev } \\
\text { For example, at a survey cond }\end{array}$ & $\begin{array}{l}\text { monthly totals } \\
\text { s, and the omit } \\
\text { re dropped, bec } \\
\text { th and individu } \\
\text { vas spotty in W } \\
\text { us calendar mo } \\
\text { cted in May, in }\end{array}$ & $\begin{array}{l}\text { Cable incluc } \\
\text { group is t } \\
\text { se it was } \mathrm{p} \\
\text { The Liber } \\
\text { 1). All m } \\
\text { is was aske } \\
\text { ne was aske }\end{array}$ & $\begin{array}{l}\text { ast surve } \\
\text { ially affe } \\
\text { esults }(\mathrm{P} \\
\text { tary valy } \\
\text { estrospec } \\
\text { or Febru }\end{array}$ & $\begin{array}{l}\text { ys between Janu } \\
\text { ound before CO } \\
\text { d by COVID-19 } \\
\text { 1 A) include only } \\
\text { are in USD and } \\
\text { ely at a survey } \\
\text { March, and Ap }\end{array}$ & $\begin{array}{l}\text { and July } 2 \\
\text { (January } \\
\text { d associate } \\
\text { Jave } 2 \text { of th } \\
\text { nsorized at } \\
\text { ducted in I }\end{array}$ & $\begin{array}{l}\text { 20. Respon } \\
\text { February) } \\
\text { disruptions } \\
\text { study (sinc } \\
\text { he 99th per } \\
\text { ay or later }\end{array}$ \\
\hline
\end{tabular}


Table A9: School Meals

\begin{tabular}{lcc}
\hline & $\begin{array}{c}(1) \\
\text { Liberia }\end{array}$ & $\begin{array}{c}(2) \\
\text { Malawi }\end{array}$ \\
\hline $\begin{array}{l}\text { 1 if following meals were provided in school (before closure): } \\
\text { breakfast }\end{array}$ & 0.03 & 0.56 \\
lunch & 0.33 & 0.01 \\
snack & 0.01 & 0.00 \\
no food at all & 0.52 & 0.37 \\
1 if respondent reported yes to: & & \\
children miss out meals & 0.23 & 0.12 \\
respondent spends money to make more food & 0.56 & 0.76 \\
assitance from family/neighbor/friends & 0.01 & 0.00 \\
assistance from village chief/gov't/aid programs & 0.33 & 0.13 \\
\hline
\end{tabular}

Note: Questions were asked of all households and crop vendors with school-aged children. $\mathrm{N}=2029$ (507 in Liberia and 1,522 in Malawi). 